\title{
Multi-disciplinary approach to sedimentary facies analysis of Messinian Salinity Crisis tectono-sequences (South-Mansoura Area, Nile Delta): Incised-valley fill geological model reconstruction and petroleum geology-reservoir element delineation
}

\author{
Ahmed M. Elatrash ${ }^{1,2} \cdot$ Mohammad A. Abdelwahhab ${ }^{3}$ (D) Hamdalla A. Wanas ${ }^{4} \cdot$ Samir I. El-Naggar $^{5}$. \\ Hasan M. Elshayeb ${ }^{1}$
}

Received: 8 December 2020 / Accepted: 27 February 2021 / Published online: 30 March 2021

(C) The Author(s) 2021

\begin{abstract}
The quality of a hydrocarbon reservoir is strongly controlled by the depositional and diagenetic facies nature of the given rock. Therefore, building a precise geological/depositional model of the reservoir rock is critical to reducing risks while exploring for petroleum. Ultimate reservoir characterization for constructing an adequate geological model is still challenging due to the in general insufficiency of data; particularly integrating them through combined approaches. In this paper, we integrated seismic geomorphology, sequence stratigraphy, and sedimentology, to efficiently characterize the Upper Miocene, incised-valley fill, Abu Madi Formation at South Mansoura Area (Onshore Nile Delta, Egypt). Abu Madi Formation, in the study area, is a SW-NE trending reservoir fairway consisting of alternative sequences of shales and channel-fill sandstones, of the Messinian age, that were built as a result of the River Nile sediment supply upon the Messinian Salinity Crisis. Hence, it comprises a range of continental to coastal depositional facies. We utilized dataset including seismic data, complete set of well $\log$ s, and core samples. We performed seismic attribute analysis, particularly spectral decomposition, over stratal slices to outline the geometry of the incised-valley fill. Moreover, well log analysis was done to distinguish different facies and lithofacies associations, and define their paleo-depositional environments; a preceding further look was given to the well log-based sequence stratigraphic setting as well. Furthermore, mineralogical composition and post-depositional diagenesis were identified performing petrographical analysis of some thin sections adopted from the core samples. A linkage between such approaches, performed in this study, and their impact on reservoir quality determination was aimed to shed light on a successful integrated reservoir characterization, capable of giving a robust insight into the depositional facies, and the associated petroleum potential. The results show that MSC Abu Madi Formation constitutes a third-order depositional sequence of fluvial to estuarine units, infilling the Eonile-canyon, with five sedimentary facies associations; overbank mud, fluvial channel complex, estuarine mud, tidal channels, and tidal bars; trending SW-NE with a Y-shape channel geometry. The fluvial facies association (zone 1 and 3) enriches coarse-grained sandstones, deposited in subaerial setting, with significantly higher reservoir quality, acting as the best reservoir facies of the area. Although the dissolution of detrital components, mainly feldspars, enhanced a secondary porosity, improving reservoir quality of MSC Abu Madi sediments, continental fluvial channel facies represent the main fluid flow conduits, where marine influence is limited.
\end{abstract}

Keywords Sedimentary Facies Analysis · Depositional model · Reservoir Quality · Incised-valley fill · Abu Madi Formation · Onshore Nile Delta

Mohammad A. Abdelwahhab

geo.mohammad85@azhar.edu.eg;

abdelwahhabfulbright@gmail.com

1 Department of Geology, Faculty of Science, Menoufia University, Shebin El-Kom, Menoufia, Egypt

2 Exploration Department, Egyptian Natural Gas Holding Company (EGAS), Nasr City, Cairo, Egypt
3 Geology Department, Faculty of Science, Al-Azhar University, Nasr City, Cairo 11884, Egypt

4 Department of Petroleum Geology \& Sedimentology, Faculty of Earth Sciences, King Abdulaziz University, Jeddah, Saudi Arabia

5 Alamein Petroleum Company, Maadi, Cairo, Egypt 


\section{Introduction}

Reservoir characterization involves the work on depicting the reservoir heterogeneity [through analyzing and mapping depositional facies], and reservoir quality [through identifying post-depositional diagenetic processes effect on porosity and permeability], to efficiently predict the reservoir performance.

Today, reservoir characterization demands integrating various disciplines (e.g., seismic geomorphology, sequence stratigraphy, and sedimentology), comprehensively defining the reservoir characteristics, to obtain the best recoveries with fewest wells (Slatt 2013). Integrating different approaches to depicting the depositional environments/facies, and identify their effect on reservoir performance, gives a precise picture of the reservoir characteristics and improves the success rates of hydrocarbon exploration and development (Abdel-Fattah and Slatt 2013; Abdel-Fattah 2014; Pigott and Abdel-Fattah 2014; Abdel-Fattah and Tawfik 2015). Sediments of different depositional environments may be broadly grouped into continental, shoreline/transitional, and marine deposits. Each depositional system exhibits unique architectural features, with particular sedimentological patterns, caused by sediment transport processes and the subsequent deposition in various environments. Sizes, shapes, net-to-gross values, orientation, continuity, and other characteristics of the reservoir are a result of the sediment transport nature, depositional environment, basin configuration, tectonics, fluctuation of eustatic sea level, and climate (Slatt 2006). Therefore, building a precise geological/depositional model, capable of efficiently depicting the reservoir characteristics and controls on reservoir performance, is of utmost importance in reservoir management phases.

The Nile Delta of Egypt is considered a noteworthy depositional system, in which Nile River-Mediterranean complex interaction has been operating the geologic history for 35 million years (Said 1981; Sestini 1995; Guiraud and Bosworth 1999). Being part of the North African plate, it was covered by the Jurassic Neotethys (Kerdany and Cherif 1999). In the few past decades, it became a major focus of exploring for hydrocarbons (EGPC 1994; Nashaat 1998; Abdel Aal et al. 2000, 2001; Dolson et al. 2000, 2001; Keshta et al. 2012; Abdel-Fattah 2014; Younis et al. 2015; Abd El-Gawad et al. 2019a,b). It occupies about 250,000 $\mathrm{km}^{2}$ of the eastern Mediterranean (Kirschbaum et al. 2010). Recently, multitrillion cubic feet of gas have been discovered in the Nile Delta Basin (Barsoum et al. 2002; Niazi and Dahi 2004). Hence, it is considered an emerging area for gas (Samuel et al. 2003; Hanafy et al. 2016; El-Mowafy et al. 2018). It already gained the ultimate interest after locating the giant gas field, namely Zohr Field (Esestime et al. 2016).
The study area, South Mansoura (Fig. 1), is located within the onshore Nile Delta basin, approximately $6 \mathrm{~km}$ south El-Mansoura city; between latitudes $30^{\circ} 95^{\circ} 00^{\prime \prime}$ and $31^{\circ} 00^{\circ} 00^{\prime \prime} \mathrm{N}$, and longitudes $31^{\circ} 18^{\circ} 00^{\prime \prime}$ and $31^{\circ} 33^{\circ} 00^{\prime \prime} \mathrm{E}$. In onshore Nile Delta, sequences of Messinian age host main petroleum reservoirs of the Nile Delta Basin; Qawasim and Abu Madi formations (Dolson et al. 2001; Niazi and Dahi 2004; Leila et al. 2016). Tectonically, the Messinian age (of the Upper Miocene; 7.24-5.33 Ma) represents a critical time period in the Mediterranean Sea evolution; in which isolation from waters of the Atlantic Ocean (Garcia-Castellanos et al. 2009), upon Messinian Salinity Crisis (MSC) seal level fall (Barber 1981), led to the accumulation of evaporites in deep-sea sites and widespread erosion on land. During MSC lowering of sea level and upon recovery, transgression at the close of Messinian, sedimentary infills (e.g., Eonile canyon, Fig. 1) incised into, and buried beneath, the thick Plio-Pleistocene sediments; forming the canyon/incised valley fluviodeltaic Abu Madi Formation (Hsü et al. 1973; Ryan et al. 1973; Said 1990; Salem et al. 2005; Leila and Moscariello 2019). Besides the episodes of widespread land erosion, the MSC incisions were accompanied by cyclic fluctuations of climate, from arid conditions to humid, resulting in huge changes in physiography of North African margin together with the Nile Delta Basin (Griffin 1999, 2002; Leila et al. 2018). Influences of such physiographic changes on the composition of syn-MSC sediments, in terms of type and rate of sediment supply, are poorly controlled.

After discovering the gas of Abu Madi Field, in 1960s, from these incised valleys, the MSC facies became a major focus for hydrocarbon exploration (Abdel Aal et al. 1994; Dalla et al. 1997; Dolson et al. 2001). Given the MSC Abu Madi sediments were being deposited under complex conditions of climate and depositional environments, the depositional and diagenetic facies were also certainly being affected. This, in turn, has a significant impact on the reservoir quality of Abu Madi facies (Salem et al. 2005; Leila et al. 2016, 2018, 2019); as a range of continental (fluvial) to estuarine (deltaic) facies constitute Abu Madi Formation (Sharaf et al. 2004; Salem et al. 2005; Leila and Moscariello 2019; Leila et al. 2020). Hence, the depositional setting, architecture, and diagenetic evolution of MSC Abu Madi facies still convey a big uncertainty for exploration and development strategies. Moreover, the Eonile infill models have not been yet totally established, in which questions about the genesis of the current incised valley model (Zaitlin et al. 1994; Shanley and McCabe 1994) still rise; whether or not it may apply to Messinian incised-valley context, where magnitude of incision, timing, and subsequent infill are not matching with the ones caused by global eustatic sea level changes (Breda et al. 2007). Although some recent investigations addressed El-Mansoura Concession (e.g., Leila and Moscariello 2017; Abu El-Ata et al. 2019; Leila 2019; 
Fig. 1 Location map of South Mansoura area within Nile Delta Basin, with main structural elements (adopted and modified after Leila et al. 2019)

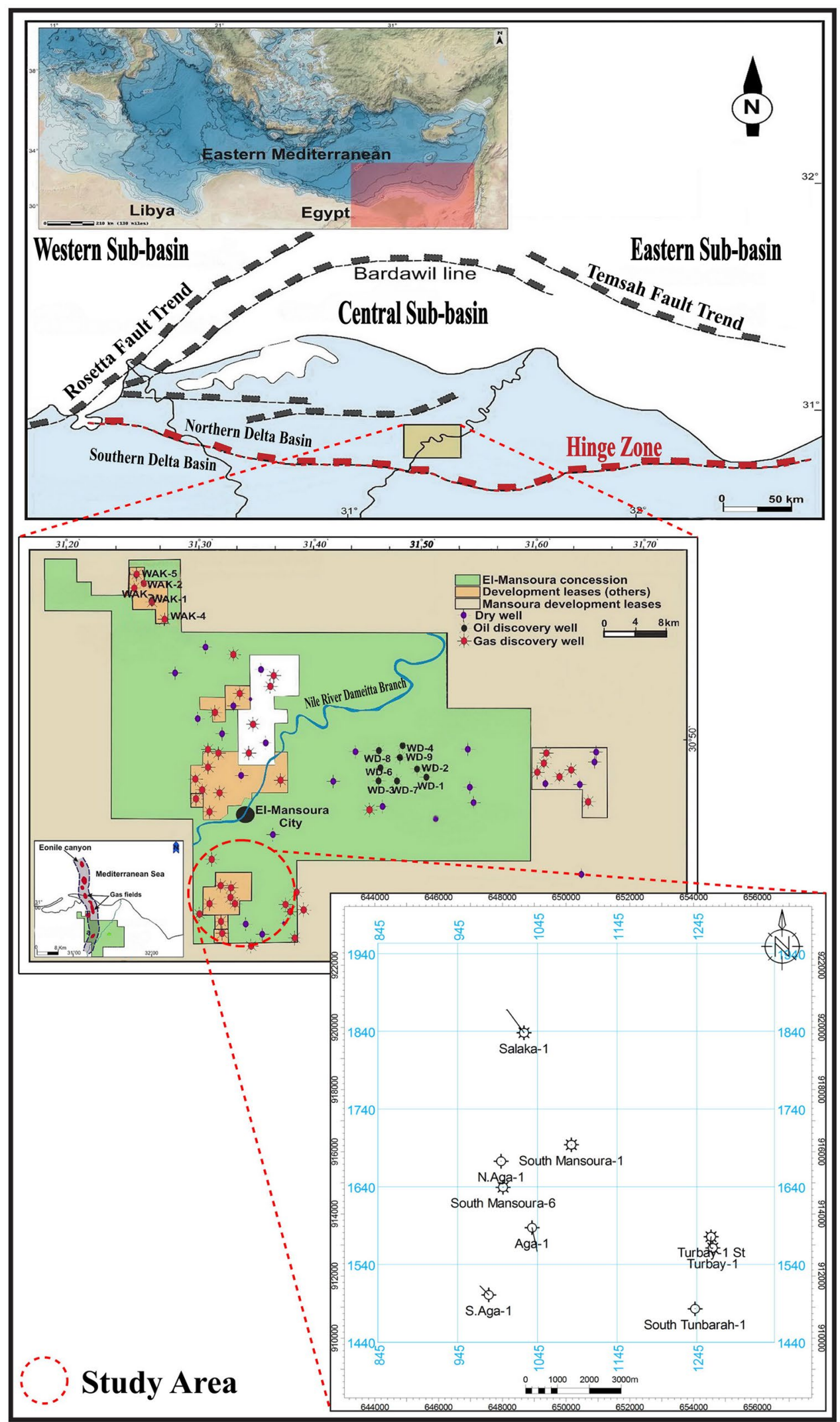


Hussein et al. 2020; Leila and Mohamed 2020), they were mainly concerned with geochemical and sedimentological patterns, far from South Mansoura Area; moreover, pre- and post-MSC rather than syn-MSC. Hence, ultimate characterization of South Mansoura MSC reservoir, particularly its paleoenvironmental settings and their impact on reservoir quality, has not been satisfactorily achieved. Furthermore, Said (1990) and Abdel Aal et al. (1994) interpreted MSC Abu Madi sediments as lateral onshore equivalent to MSC offshore evaporite facies (Rosetta Formation). Nonetheless, no detailed sedimentary facies analysis was carried out to reveal the paleoenvironmental conditions controlled the sediment deposition. In addition to this, a further uncertainty over stratigraphic relationships between pre-MSC and MSC facies still arises. In this study, we combined multiple facies-based disciplines; seismic geomorphology, sequence stratigraphy, and sedimentology; to efficiently depict the depositional and diagenetic setting of Messinian Abu Madi incised valley fill in the onshore Nile Delta. This study uses a considerable range of dataset (seismic data, well logs, borehole images, and core data) to provide an unequalled opportunity to delineate the paleoenvironmental depositional conditions of the MSC event, depicting the reservoir heterogeneity and quality that are significant key parameters in justifying further hydrocarbon exploration and development plans of the area.

\section{Geologic setting}

The Nile Delta of Egypt occupies the quite deformed northern edge of the African plate; interposing three major tectonic regions (Red Sea/Gulf of Suez rift, Syrian Arcing system, and African-Anatolian plate) (Said 1990; Sarhan and Hemdan 1994; Harms and Wray 1990). Its structural and stratigraphic setting went a subject of interest by several authors (Zaghloul 1976; Ross and Uchupi 1977; Sestini 1989; Loncke et al. 2002; Saleh 2012, 2013; SELIM 2016; Hanafy et al. 2017). Particular emphasis, addressing geometry, architecture, and associated petroleum potential, was given to the onshore Nile Delta (e.g., El Nady 2007; El-Din et al. 2013; Krott et al. 2015; Abd El-Wahed and Anan 2016; Ghassal et al. 2016; El Khadragy et al. 2017; Teama et al. 2018; Abu El-Ata et al. 2019).

Serious structural behavior has shaped the Nile Delta's sedimentary patterns; hence divided it into many subbasins (Ross and Uchupi 1977; Kamel et al. 1998; Gargani et al. 2008). An east-west faulted flexure, namely hinge, zone subdivides the Nile Delta Basin into northern and southern sub-basins (Fig. 1) (Abu El-Ella 1990; Kamel et al. 1998; Mohamed et al. 2013; Makled et al. 2017). The northern sub-basin features some listric extensional faults
(Zaghloul 1976; Schlumberger 1984); while the southern one exhibits a number of asymmetrical folds belonging to the Syrian Arc folding system (Zaghloul 1976). The hinge zone is a consequence of the Jurassic southern Neo-Tethys break-up. It represents not just a tectono-structure boundary but also a facies boundary; Upper Cretaceous carbonate shelf edge (Leila and Moscariello 2019); (Leila et al. 2016). It imparts recognized impacts on tectonic evolution of the Nile Delta Basin, causing thickening of Tertiary sediments basinward (Sestini 1995). Besides, northeastsouthwest Rosetta and northwest-southeast Temsah faults subdivide the northern Nile Delta into western, central, and eastern sub-basins (Lashin and Mogren 2012; Hanafy et al. 2018). Deep-seated faults that run parallel to the Hinge Zone serve as migration pathways to hydrocarbons from source rocks; Upper Cretaceous-Lower Paleogene, and Jurassic sediments; to reservoir ones; Miocene sediments (Shaaban et al. 2006; Vandré et al. 2007; Leila and Moscariello 2017).

The stratigraphic column of the Nile Delta ranges in age from Precambrian to Recent (Schlumberger 1984; Abu El-Ella 1990; El Diasty and Moldowan 2013). The penetrated sedimentary succession is ended at the Jurassic (Fig. 2). Despite that, the petroleum potential is broadly limited to Neogene-Quaternary clastics (Leila et al. 2016; Nabawy and Shehata 2015). Neogene-Quaternary sediments of the Nile Delta have been grouped into three sedimentary cycles; Miocene, Pliocene, and Pleistocene (Said 1962; Ross and Uchupi 1977; Rizzini et al. 1978; Kamel et al. 1998). The shallow marine carbonates, Upper Jurassic, represent the oldest rock units penetrated in the area (Fig. 2) (Abdel Aal et al. 1994). The Lower Cretaceous is dominated by shallow marine facies (Guiraud and Bosworth 1999). During the Upper Cretaceous, the environment of deposition changed from open-marine to marine-alluvial sediments; before returning back to marine conditions upon the end of Cretaceous (Said 1990; Guiraud and Bosworth 1999). The Late CretaceousEocene sequences are relatively thin because of Syrian Arc folding (Harms and Wray 1990). The Oligocene deposits consist of relatively thick coarse-grained siliciclastic fluvial facies (Harms and Wray 1990; Said 1990). Two notable unconformities are recorded in Miocene-Pliocene sequences (Rizzini et al. 1978; Barber 1981; Harms and Wray 1990; Said 1990). The first one separates the Middle Miocene from strata of the Upper Miocene, while the second one corresponds to Messinian Salinity Crisis desiccation event; upon forming Abu Madi incisions (Leila and Moscariello 2019). During the Lower Pliocene, marine transgression occurred, covering the Nile Delta Basin with marine Kafr El-Sheikh sediments (Ross and Uchupi 1977; Said 1990; Gargani and Rigollet 2007). 
Fig. 2 Stratigraphic succession of onshore Nile Delta (adopted and modified after Corex 2007; Leila and Mohamed 2020)

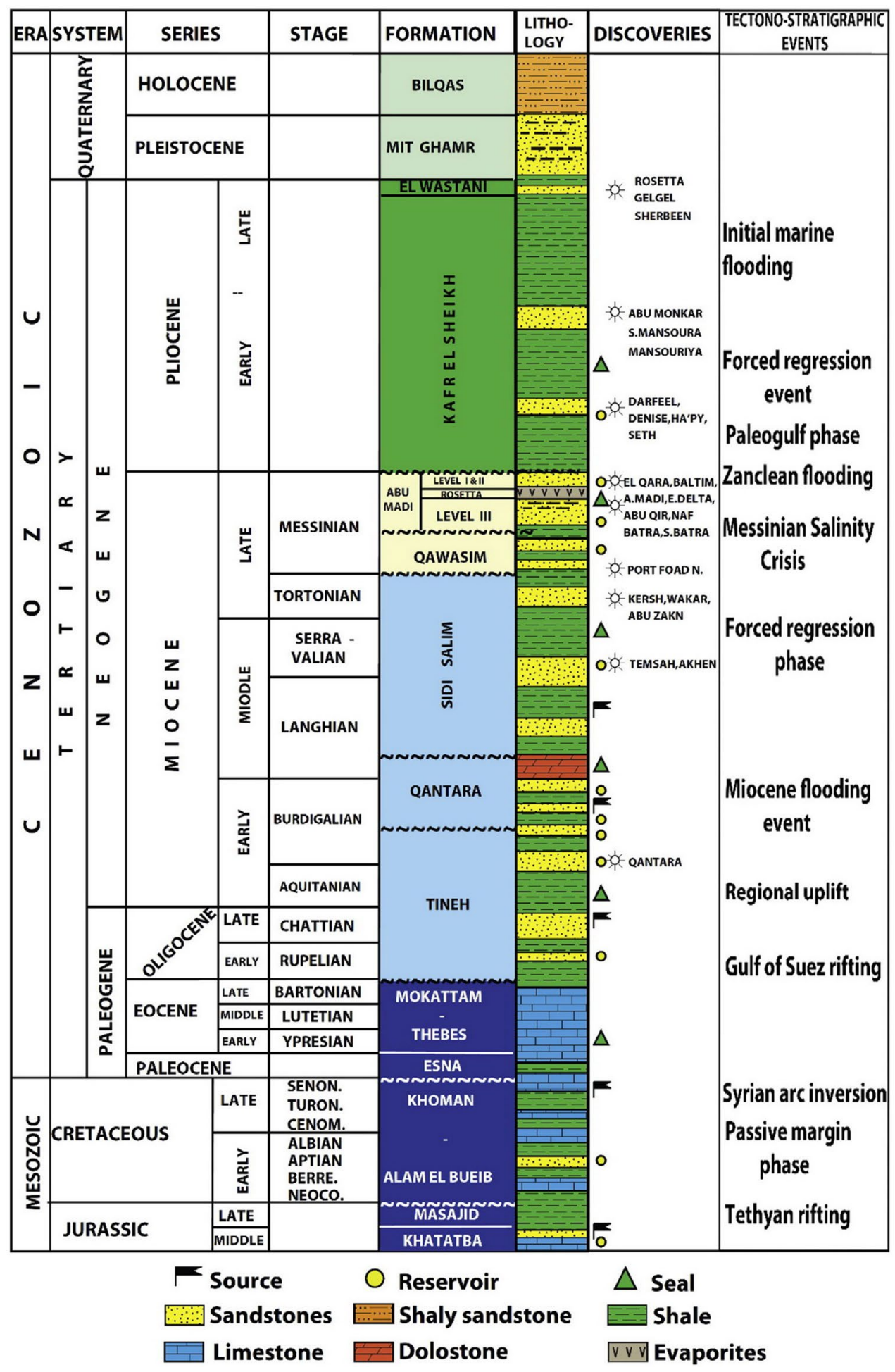

\section{Data and methodology}

Dataset utilized in this work include post-stack seismic data (Fig. 1), time-depth relationships, well logs (e.g., gamma-ray, spontaneous potential, resistivity, sonic, neutron, density, and FMI/borehole image) with age-identified interpreted stratigraphic tops, and thin sections adopted from core samples. This work implemented a multi-disciplinary approach; integrating various sedimentary facies-depicting disciplines (e.g., attribute-based seismic geomorphology, sequence stratigraphy, and sedimentology); using software program tools such as Petrel, and Techlog. 
The post-stack seismic data of this study are dominated by a frequency range of 0-60 Hz (Fig. 3), with an approximately 13,20 , and $30 \mathrm{~Hz}$ predominant frequency values at the zone of interest. Seismic to well tie, corresponding stratigraphic horizons to seismic reflectors, was a first required step for interpreting seismic profiles (Abdelwahhab and Raef 2020). Linking tops of stratigraphic horizons to the corresponding seismic reflectors was achieved, in this study, using the established one-dimensional synthetic seismograms; an example is shown in Fig. 4. Synthetic seismic traces were a result of the convolution of reflectivity series (produced from sonic and density logs) and extracted wavelets (White and Simm 2003). A preceding step of well-log QC (quality control) analysis, that fixes log spikes, was done for a better generation of synthetic seismic traces used in seismic well tie. Mis-ties are caused due to signal-noise ratio or when real seismic traces do not have the same wavelets of synthetic ones (Ziolkowski et al. 1998; HENRY 2000). The produced synthetic traces were then matched with real seismic data. Upon reaching a satisfying seismic to well tie, with about 0.7 correlation coefficient, stratigraphic tops were picked throughout the entire seismic data.

Methods of analyzing depositional and diagenetic facies used in this work include: (1) seismic attribute, particularly frequency spectral decomposition, analysis so as to depict the planer distribution/geomorphology of sedimentary facies; (2) sequence stratigraphic framework and depositional facies analysis based on well log data (e.g., gammaray $\log$ response, and borehole image interpretation); (3) reservoir properties (e.g., porosity, and permeability) determination based on conventional well log analysis, applying several equations and cross-plots; (4) thin section petrographic analysis, examining nineteen samples with conventional petrographic microscope, to determine the mineralogical composition and define the post-depositional diagenetic processes and their impact on reservoir quality. Mineralogical modal composition was obtained through whole rock XRD analysis and point counting technique (Gazzi 1966; Dickinson 1970). Sandstone classification was introduced following Folk (1980); (5) paleogeomorphologic configuration and filling model reconstruction to establish the paleodepositional system controlled sediment/reservoir heterogeneity and quality, from source to sink.

\section{Results and discussions}

\section{Seismic geomorphology}

Seismic sedimentology is basically a seismic-based analysis of sedimentary rocks (rock and fluid property) and their paleo-depositional environments. It provides

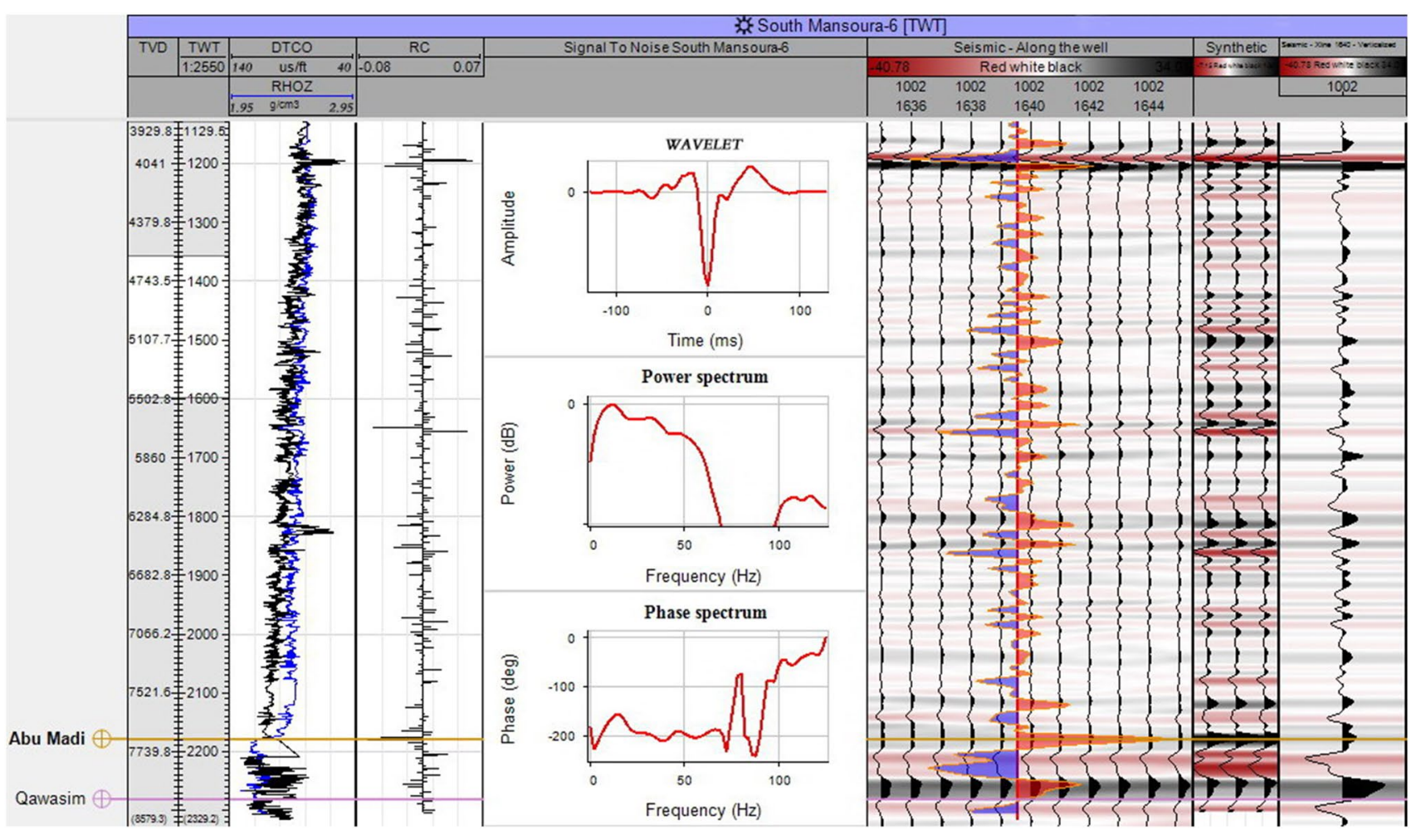

Fig. 3 Synthetic seismogram of South Mansoura- 6 well, displaying the seismic to well tie 


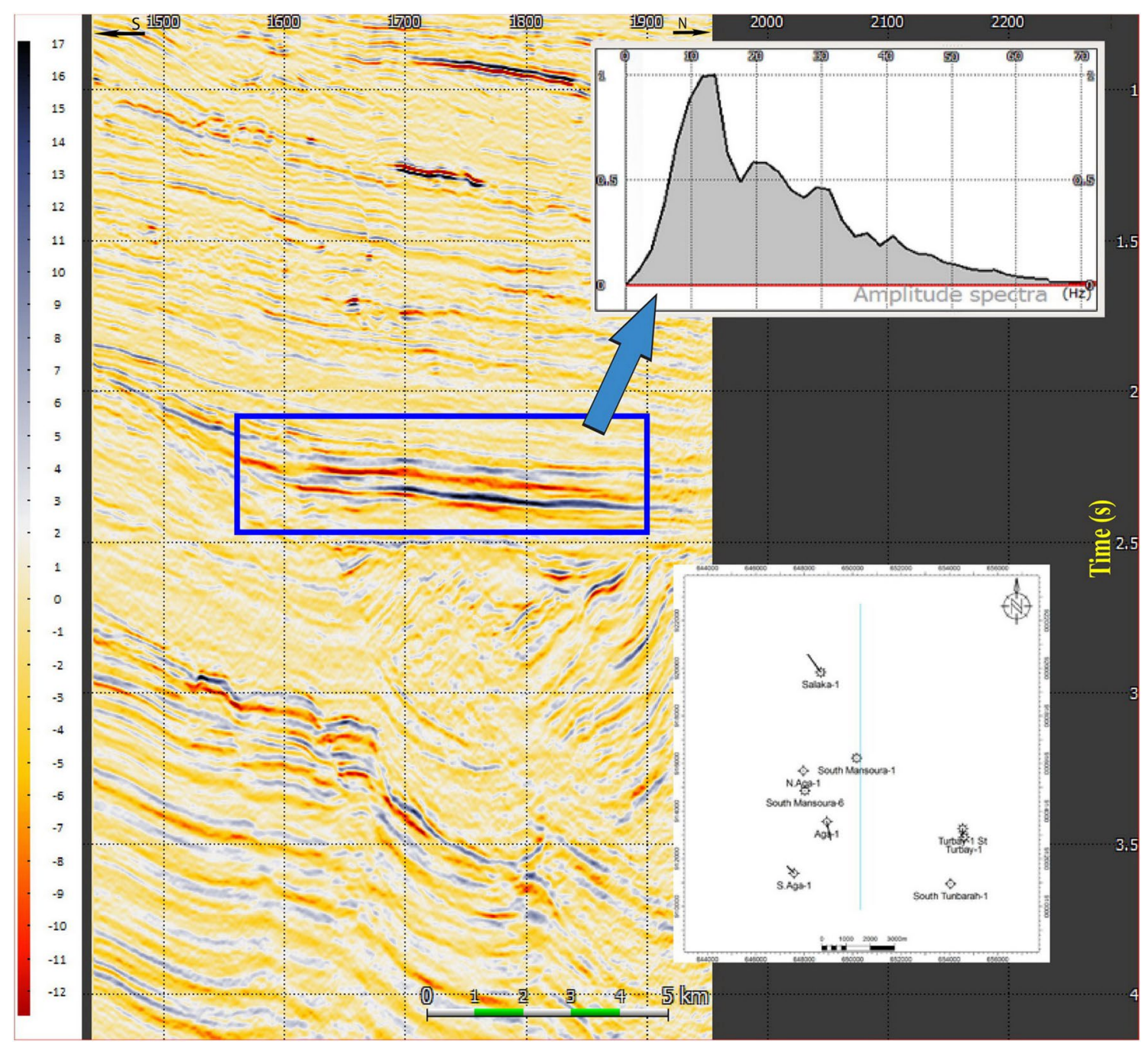

Fig. 4 Inline seismic profile with amplitude spectrum range of the zone of interest

litho-geomorphologic mapping of sedimentary facies, particularly when combined/calibrated with other related approaches (e.g., well-log analysis) (Zeng et al. 1998a; Zeng and Hentz 2004). Seismic geomorphology is a key component of seismic sedimentology. It reveals the litho-geomorphologic distribution of sedimentary facies. Stacked and time-migrated seismic data, and amplitude attributes, are of use as a starting point. Several advanced approaches exist (e.g., seismic attribute analysis (Chopra and Marfurt 2007), AVO analysis (Chopra and Castagna 2014), seismic inversion (Cooke and Schneider 1983; Russell and Hampson 1991), and multicomponent seismic (Hardage et al. 2011)) (Zeng et al. 2020). Such approaches are beyond our paper's scope; except seismic attribute analysis, particularly spectral decomposition. Several seismic attribute related approaches were performed in this study; e.g., frequency spectral decomposition and fusion/ blending, stratal slicing (horizon stacking), and relative acoustic impedance; so as to depict the planer litho-geomorphology of facies.

Spectral decomposition and fusion involve the process of partitioning the seismic traces, in the time domain, into various frequency bands and subsequently recombining the frequency panels so as to improve the visual effect of the sedimentary geometries (Zeng 2017); and delineate stratigraphic settings (e.g., channel sands) (Partyka et al. 1999). In fact, new seismic attributes are generated and can then be displayed in RGB (red-green-blue) color blending form. Choices of frequency panels are determined considering the desired thickness interval to visualize; with low frequency adjusted to thick sandstones and high frequency adjusted to thin beds. Frequency fusion/blending considerably reduces the thin-bed tuning effect through applying multiband tuning (tuning in expanded thickness), generating realistic view of lithostratigraphic geometries (Zeng et al. 2020). In this work, three frequency panels; at 13, 20, and $30 \mathrm{~Hz}$ (Fig. 5a); 
Fig. 5 Crossline 1680 seismic profile, showing RGB frequency decomposition and STDFT spectral decomposition
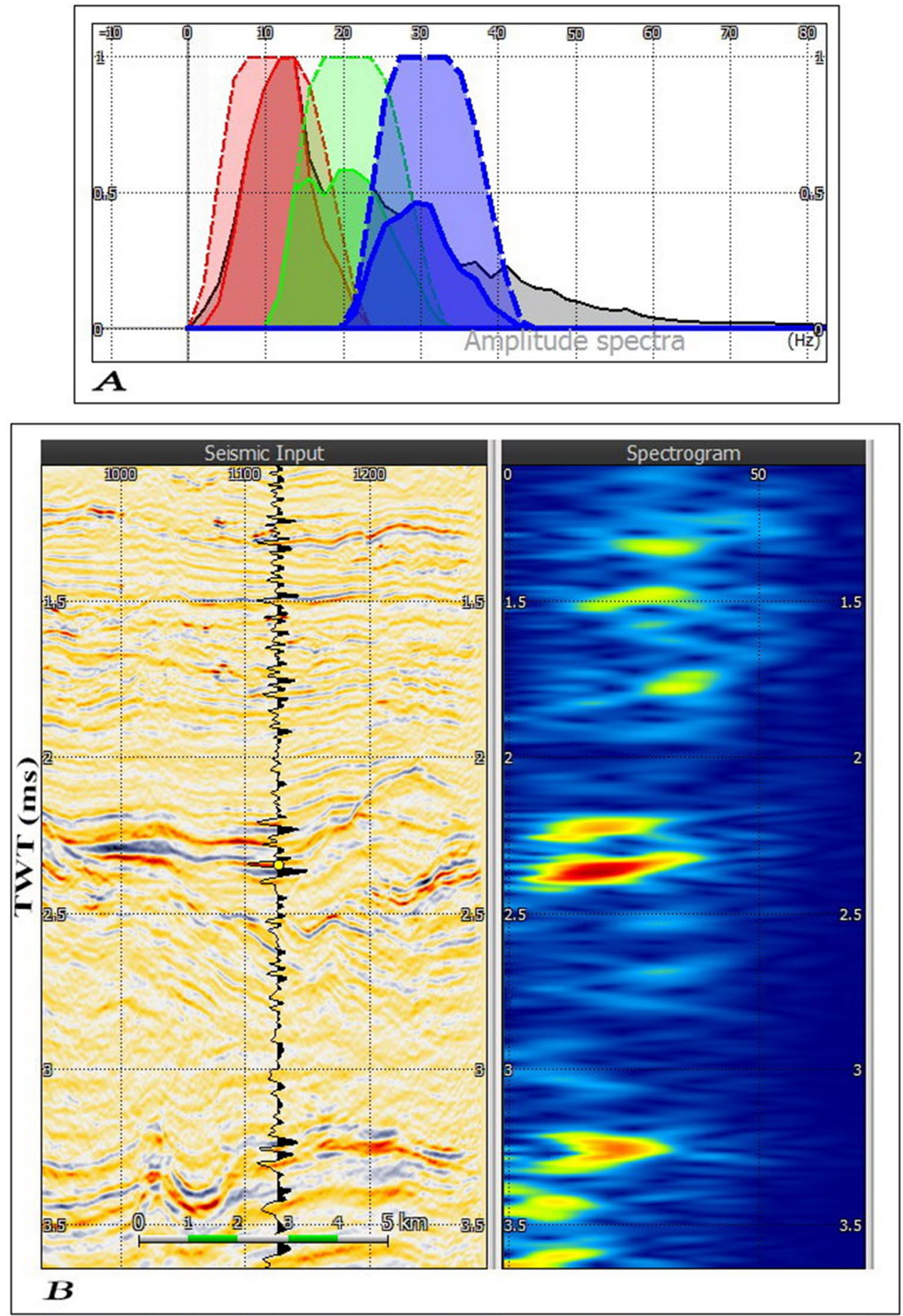

were chosen in the process of amplitude spectrum frequency decomposition (Fig. 5b); applying short-time discrete Fourier transform (STDFT) spectral decomposition following Partyka et al. (1999). $13 \mathrm{~Hz}$ frequency is adjusted to thick beds (Fig. 6a), $20 \mathrm{~Hz}$ to moderate ones (Fig. 6b), and $30 \mathrm{~Hz}$ to thin ones (Fig. 6c).

Typically, depositional surfaces picked on seismic profiles follow geologic time. For geologic time-related seismic events, auto-tracking of seismic reflections may satisfy application purposes. However, for other certain events, stratal slicing (Zeng et al. 1998a, b) would be the proper choice. A stratal slice is a phantom slice generated following sediment-accumulation model and does not inevitably follow the same seismic phase. The stratal slicing removes structural influences on the horizontal seismic slices so as to analyze and interpret stratigraphic features (Zeng et al. 
Fig. 6 Frequency panels, at 13, 20 , and $30 \mathrm{~Hz}$ adjusted to thick, moderate, and thin beds
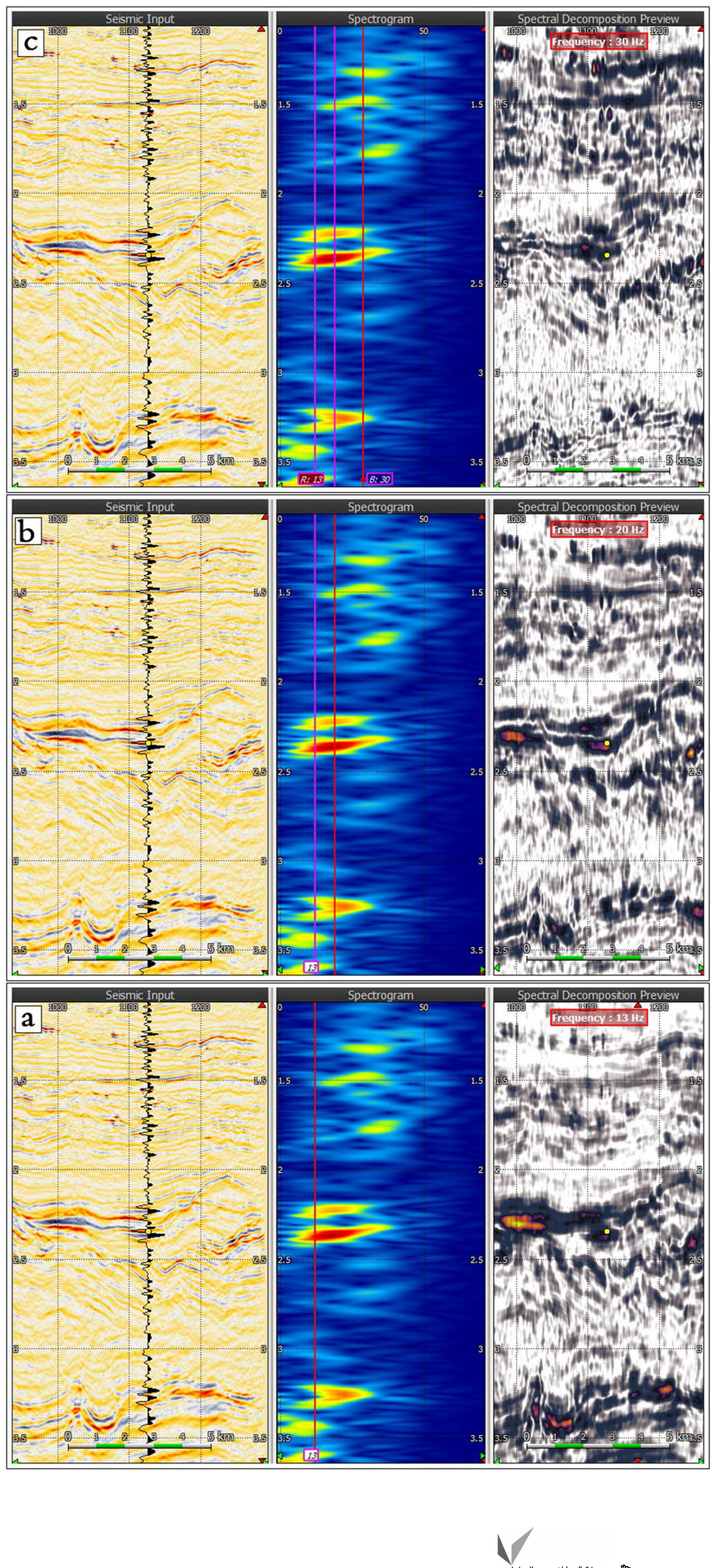

Springer 
2020). In this work, 300 stratal slices (horizon stacks) were generated between seismic reflections, at selected zone of interest over seismic data, preceded by geo-model grid construction. RGB blended frequency slices (Fig. 7a) are the principal displays of the seismic litho-geomorphologic facies depicted in this study.

Relative acoustic impedance attribute is calculated by integration of original seismic trace followed by passing a low cut filter (Latimer et al. 2000). It provides an indication of impedance change, boundaries of sequences, porosity content, unconformities, and discontinuities in reservoirs (Subrahmanyam and Rao 2008). In this study, relative acoustic impedance attribute was extracted to maximize capturing of the potential effect of channel incisions and lithofacies variations within the Messinian Salinity Crisis sequences.

Figure 8 is an interpreted seismic section for pre-, syn-, and post-Messinian sequences. It obviously shows the sequence of syn-MSC Abu Madi infills incision into preMSC Qawasim Formation. The bottom erosion surface of Abu Madi sequence dips basinward and displays an asymmetrical depression, about $7 \mathrm{~km}$ wide, (Eonile canyon). Abu Madi infills are traced between 2150 and $2430 \mathrm{~ms}$ TWT. They represent a channel-fill morphology where the MSC Abu Madi facies demonstrate bidirectional onlap terminations across channel walls. On well log data the top and bottom surfaces of MSC Abu Madi infills are marked by a sharp break in GR values; reflecting their erosional characteristics and noticeable change in depositional facies, due to different tectono-sediment supply abiding environments, between preand post-MSC facies. Abu Madi infills pinch-out towards margins of the Eonile canyon, where they reach about $35 \mathrm{~ms}$
TWT thickness; and thicken towards the depression center, where they reach $200 \mathrm{~ms}$ TWT thickness approximately. The RGB blended frequency slice (Fig. 7a) depicts the litho-morphologic facies distribution of Abu Madi incised valley fill. It shows a SW-NE trending reservoir fairway, with a Y-shape channel geometry. It reveals higher anomalous regions with the interpreted paleovalley (dashed). This interpreted area of incised valley seems to be of most promising locations for both fluvial reservoir lithofacies and hydrocarbon potential. Moreover, stratal slice of relative acoustic impedance (RAI) (Fig. 7b) shows sinuous feature and Y-shape fluvial lithofacies geometry (with high values), which is in agreement with the spectral decomposition results (Fig. 7a).

\section{Sequence stratigraphy and depositional facies analysis}

Lithostratigraphic correlation, displaying variation of thickness, may provide clues to areas of subsidence and others of uplifting. However, controls on sediments' temporal and spatial distribution can be adequately defined through sequence stratigraphic models (Braaksma et al. 2006). Sequence stratigraphic analyses divide stratigraphic records into depositional sequences with boundaries marked by subaerial erosion (unconformity) surfaces or their correlative conformities (Mitchum et al. 1977). A sequence boundary marks abrupt basinward shift in the deposition, and is therefore interpreted from the sharp shallowing of depositional facies (lowering of sea level) across erosion surfaces (H W Posamentier and Vail 1988). Fluvial to estuarine sediments, in the study area, are composed of
Fig. 7 Crossline 1680 seismic section, showing Abu Madi sediment infills onlapping on channel walls. IL and XL stand for seismic inlines and crosslines, respectively

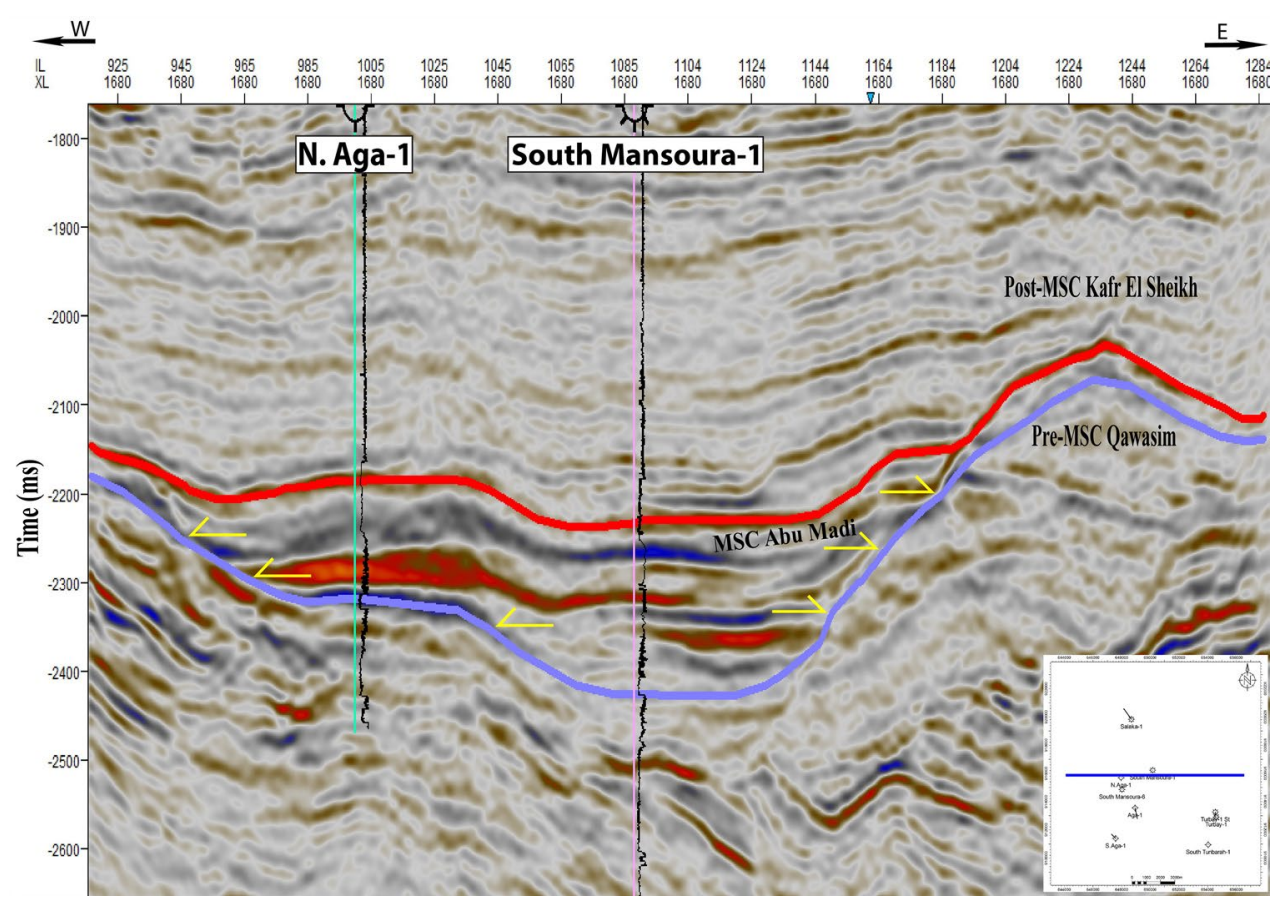


Fig. 8 Stratal slices of a RGB frequency fusion, showing channel geomorphology, and

b RAI map, showing higher values corresponding to channel geometry
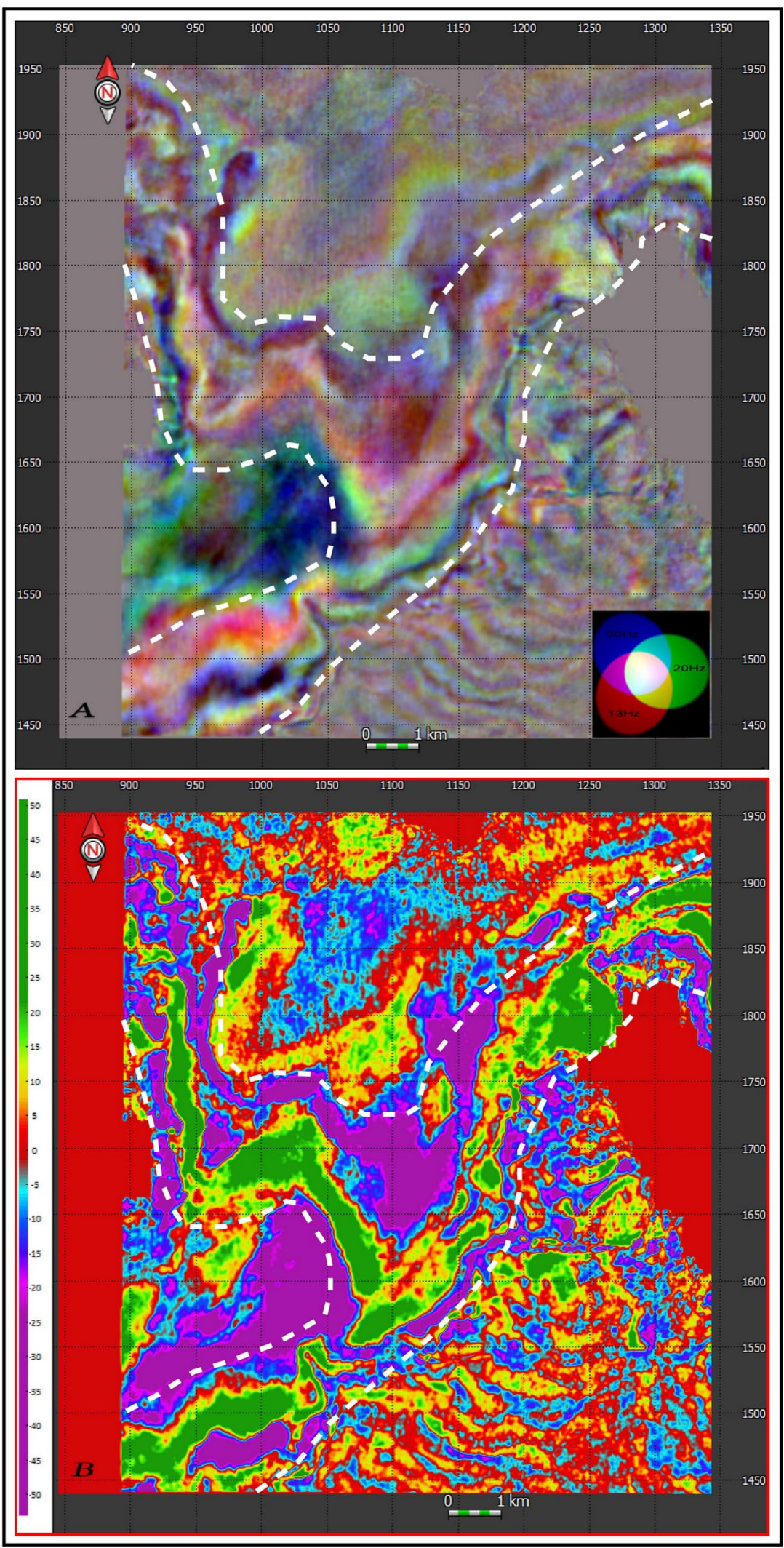
sandstone and shale interbed cycles, seen on GR shaliness $\log$ (Fig. 9). Sequence stratigraphic analyses were guided by models and principles of fluvial sequence stratigraphy following Wright and Marriott (1993), Legarreta and Uliana (1998), and Catuneanu et al. (2006). The well log-based sequence and depositional facies correlation, as shown in Fig. 9, emphasized changes in relative sea level; marking third-order depositional sequences; and depositional systems and facies associations in the study area. We recognized one third-order depositional sequence, formed in a continental shelf setting, predominates Abu Madi Formation. It is built upon lateral and vertical shift between fluvial, and estuarine facies. Abu Madi sequence stratigraphic subdivision demonstrates the stacking patterns and stratigraphic framework of different lithologies/lithofacies preserved in the area of study, and helps define historical stages of change in base level which marks the evolution of Abu Madi Formation during the Messinian Salinity Crisis.

Conventional cores provide the most reliable evidence of depositional environment and facies. Lithology, grain size, color, and sedimentary structures point to fine-scale changes in bedforms, facies, and environments of deposition (Zeng et al. 2020). In this study, due to unavailability of conventional cores, gamma-ray (GR) log patterns were used, instead, to provide means of paleo-depositional environment and facies association interpretation. Five GR motifs (Fig. 9) were used to reveal the log facies; BL (blocky) for thick distributary channel fills, FU (fining upward) for moderately thick fluvial channel fills, FL (finger-like) for thin estuarine tidal channel sandstones, CU (coarsening upward) for moderately thick estuarine sand bars, SE (serrated) for overbank/ floodplain (higher GR) and estuarine (lower GR) fines/mud; following Selley (1978), Cant (1992), Emery and Myers (1996), Chow et al. (2005), and Nazeer et al. (2016). Moreover, borehole image (FMI) logs (Figs. 10 and 11), were used to maximize the interpretation of lithofacies associations.

In the study area, Abu Madi Formation (Fig. 9) discloses fluvial to estuarine depositional systems, with five facies associations. From bottom upwards, overbank/flood plain muds and braided to meandering fluvial channel complex, followed by tidally influenced channels, then tidal channels, bars, and estuarine mud deposits at pure estuarine regime.

The overbank/flood plain mud facies association is composed of massive mudstone lithofacies with minor laminations, as revealed from the borehole image log (Fig. 10). It is generally characterized by intercalations of fine-grained siltstones and very fine sandstones. It is exhibited as a serrated pattern of the GR $\log$, reflecting silty to mud dominated deposits suggesting fluctuation of charge rate during floodplain deposition.

The fluvial channel facies association incises into flood plain muds, which may act as a lateral stratigraphic sealing to reservoir intervals, with stacked channel-fill sandstones. It consists of massive sandstone lithofacies subordinated with cross-bedded ones (Fig. 10), indicating high-energy sedimentation and erosion likely to fluvial channels (Miall 1977; Tucker 2001), followed by parallel and cross-laminated sandstones and mudstones (of estuarine setting). It lacks any bioturbation confirming continental freshwater setting. It lacks any mudstones indicating elevated hydrodynamic flow setting. It shows fining upward pattern of GR log, with coarse, medium, to fine grains upwards (graded bedding) (Figs. 11a, b, 12a, b, c, and d; Table 1). It is conglomeritic in parts (Fig. 11c), suggesting rapid sedimentation of bedload (Reineck and Singh 1980). Lower parts of the fluvial facies are characterized by uniform dipping suggesting unidirectional paleocurrent flow (of fluvial dominated systems). Multiple scour surfaces covered with conglomerates and existence of stacked units with deficiency of mudstones indicate repeated channel incisions and infill episodes (Miall 1996; Bridge 2011). It acts as the main hydrocarbon reservoir facies in the study area. It is characterized by an average effective porosity of $25 \%$ (Fig. 10). The fluvial sedimentation was confirmed by the moderate to high sinuosity fluvial channel geomorphology on the RGB spectral decomposition and extracted relative acoustic impedance mapping (Fig. 7a, $b$, respectively).

The estuarine tidal channel facies association includes cross-laminated sandstone and massive sandstone lithofacies (Fig. 10). It shows finger-like GR motif, reflecting waning charge regime in tidal dominated setting, with lenticular body appearance. The massive lithofacies may be due to the intense bioturbation dominated in the depositional system. The dominance of bioturbation supports the upward shift from continental to marginal marine setting.

The estuarine tidal bar facies association includes parallel lamination and cross-laminated sandstone lithofacies subordinated with massive sandstones (Fig. 10). It exhibits a coarsening upward pattern of the GR log, indicating the bar system. The existence of parallel and cross-lamination, with low dipping stratification, points to the fluctuation of deposition from upper to lower charge regime of tidal condition.

The estuarine mud facies association consists of laminated and massive mudstone lithofacies (Fig. 10), with local deformation. The existence of laminated and massive lithofacies reflects the suspension fall-out in calm flows. The local deformation may be a result of extensive bioturbation activity or micro-faults.

\section{Petrography and post-depositional diagenesis}

The studied samples, nineteen thin sections, of MSC Abu Madi Formation were subjected to detailed petrographic and post-depositional diagenetic analysis. Grain sizes were determined through measuring the longest axes of several grains per sample, calculating the mean value. Sorting and 
Fig. 9 SW-NE stratigraphic correlation panel, revealing the depositional sequences and facies associations

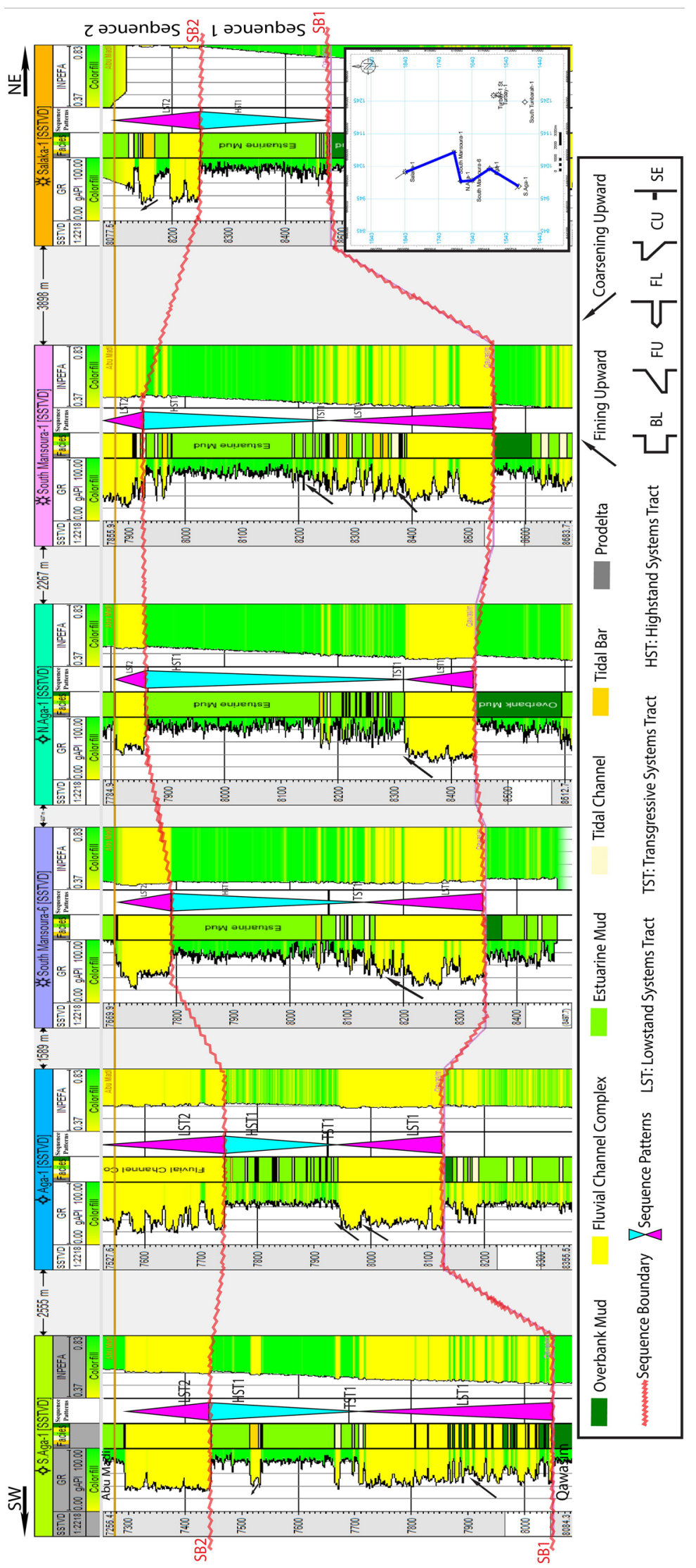


Fig. 10 Composite CPI plot, with borehole image, showing the MSC Abu Madi mesoscopic reservoir heterogeneity and quality

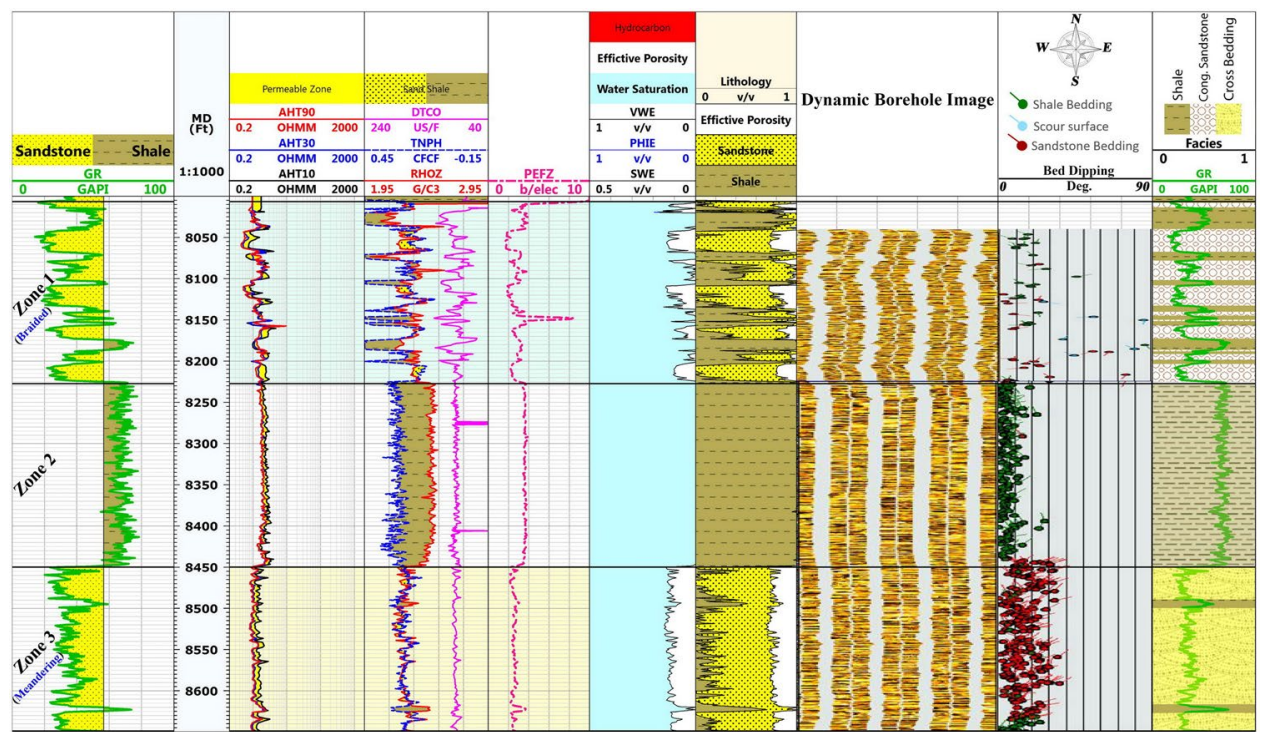

roundness of grains were defined using standards of Pettijohn et al. (1972); poorly sorted, moderately sorted, wellsorted, and very well-sorted. Roundness is displayed by the degree in which sharp edges of grains have been smoothed. Defining sorting and roundness provides means of rock textural maturity and transport history that could be key parameters for predicting reservoir quality. Table 1 shows that most of the samples are generally poorly to moderately sorted, with subangular to subrounded grain texture. Ternary plots (Fig. 12e), using QFL limits of Blatt and Tracy (1996), were used to define the framework composition, microscale heterogeneity, of MSC Abu Madi sediments. The compositional, textural, and diagenetic features of Abu Madi sediments are summarized in Table 2.

\section{Depositional model and reservoir quality}

Sediment dispersal in source-sink systems correspond to "sediment routing system" that is often described in regard to feedback mechanisms and dynamic processes between various forcing conditions, autogenic and allogenic, that control sediment distribution in erosional-depositional systems (Allen and Hovius 1998; Allen 2005, 2008a, b; Densmore et al. 2007; Sømme et al. 2009, 2013; Sømme and Jackson, 2013; Prizomwala et al. 2014). The evolution of depositional systems is indicated by morphological modifications within adjacent segments (Sømme et al. 2009). What a study area experienced; including depositional filling, structural deformation, differential compaction, and erosion; could be combined to form a composite response reflecting paleogeomorphology. Paleogeomorphology is an adequate method of understanding and predicting sedimentary facies dispersal patterns within depositional systems. During sedimentation, the paleogeomorphology and sediment charge, as well, control the spatial distribution of sediments within different depositional systems operating the basin (Martin 1966; Richards et al. 1998; Zeng and Hentz 2004; Posamentier 2004; Posamentier et al. 2007; Seidel et al. 2007; Masrouhi et al. 2008; Masini et al. 2011; Dumont et al. 2012; Zhu et al. 2014). Therefore, paleogeomorphologic restoration is a crucial approach in reconstructing depositional systems/models and predicting reservoir-quality rock distribution (Liu et al. 2016).

Paleogeomorphological architecture of the study area is dominated by the incised valley channel geometry. Positive topographic units controlled the dispersal direction of incised valleys. The channel incisions gradually converged from source to sink. Appropriate geological/depositional models of channel reservoir distribution may guide the appropriate exploration and development strategies in the area. Based on the different approaches performed in this study, conceptual depositional models (Fig. 13) of MSC Abu Madi sediments have been established so as to show sediment dispersal patterns and their depositional evolution under different depositional systems. As revealed from seismic geomorphology and sedimentary facies analyses, syn-MSC Abu Madi canyon infills represent prograding fluvial to estuarine depositional systems. From bottom upwards, the sediments display a sequence changing from fluvial channel incisions, passing through estuarine tidal bars and channels, to estuarine mud. The fluvial facies association (Fig. 13a) enriches coarse-grained sandstones, deposited in subaerial distributary channels. Therefore, it has considerably high reservoir quality, in terms of porosity and permeability, relative to the estuarine facies associations, in which reservoir quality is decreased with subsequent increase in marine influence. This is quite consistent with the extracted relative acoustic impedance stratal slice 
Fig. 11 Combined borehole image (FMI) and thin section view, showing mesoscopic and microscopic reservoir heterogeneity of MSC Abu Madi sediments in zone $3 \mathbf{a}, \mathbf{b}$ and zone $1 \mathrm{c}$
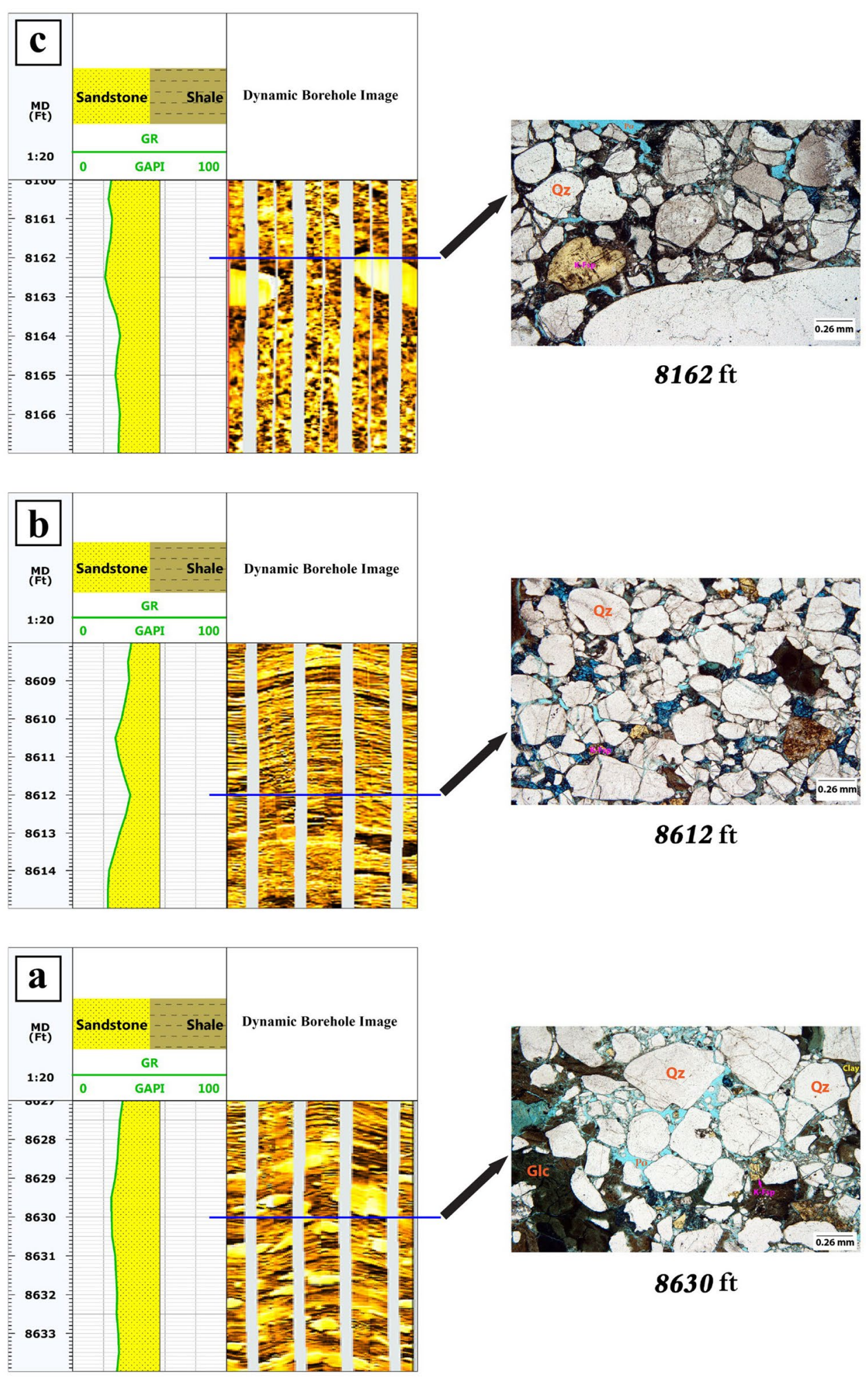

map and well log-derived porosity. A transgressive surface/event marks the boundary between the fluvial unit and the upper estuarine unit. The fluvial channel infills is followed by tidal sand bar facies, representing the onset of transgressive deposition (Fig. 13b).
The petrographic analysis maximized capturing the impact of depositional and diagenetic facies on reservoir quality. MSC Abu Madi Formation, deposited within fluvio-estuarine setting, reveals quite high degree of heterogeneity at various scales, from fieldwide to microscopic scale. Depositional 

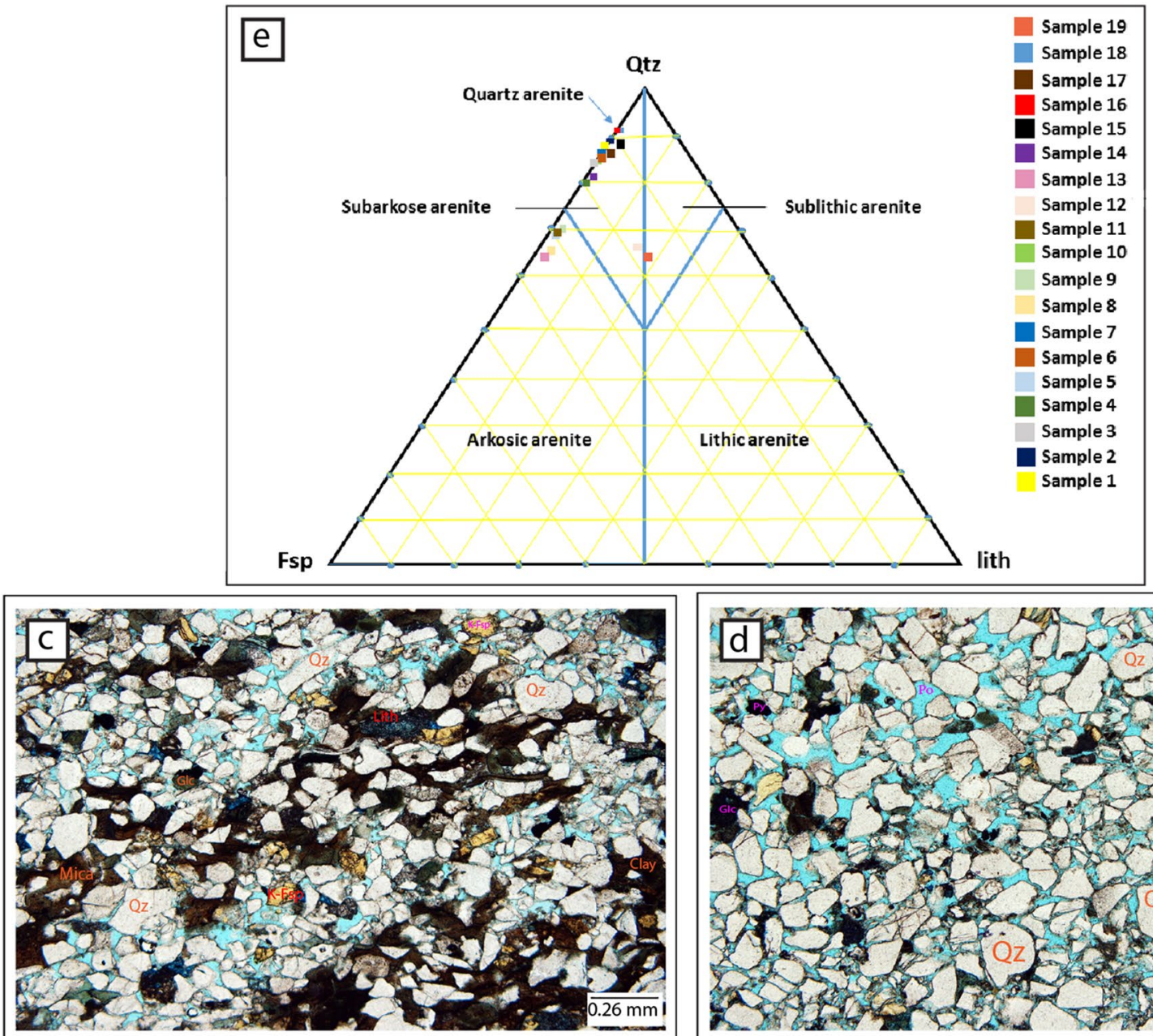

$8584 \mathrm{ft}$
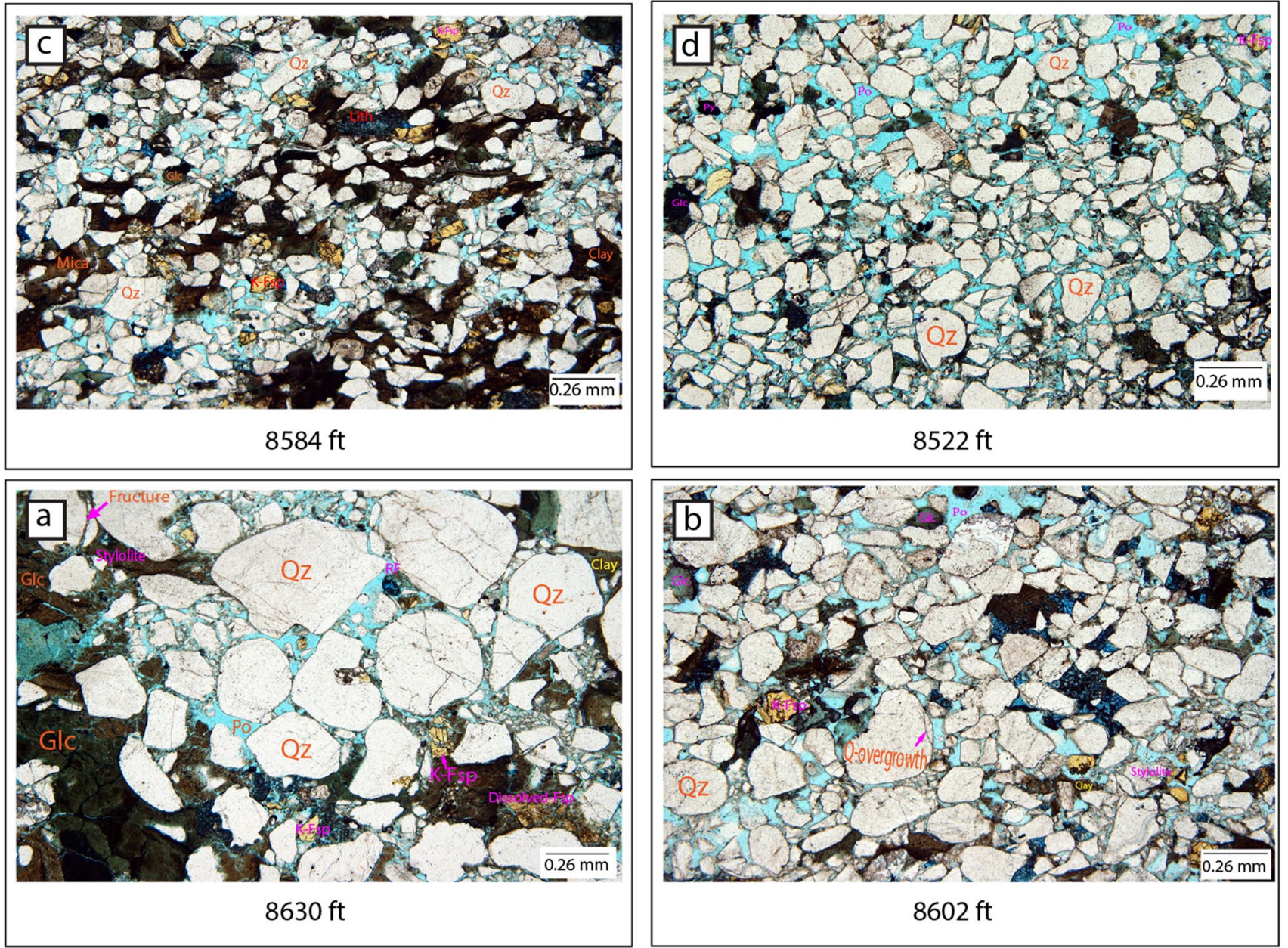

Fig. 12 Petrographic representation of Abu Madi Formation in zone $3 \mathbf{a , ~ b , ~ c , ~ d , ~ a n d ~ Q u a r t z - F e l d s p a r - L i t h i c s ~ ( Q F L ) ~ t e r n a r y ~ p l o t ~ e ~}$

facies heterogeneity is considered one of the chief controlling factors on reservoir porosity and permeability (Yassin et al. 2018). Diagenetic processes, such as compaction, cementation, and dissolution, are another factor affecting reservoir quality (Bloch 1991). Generally, the fieldwide and macroscopic (interwell) scale heterogeneity is mainly controlled by depositional

1.

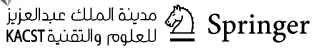




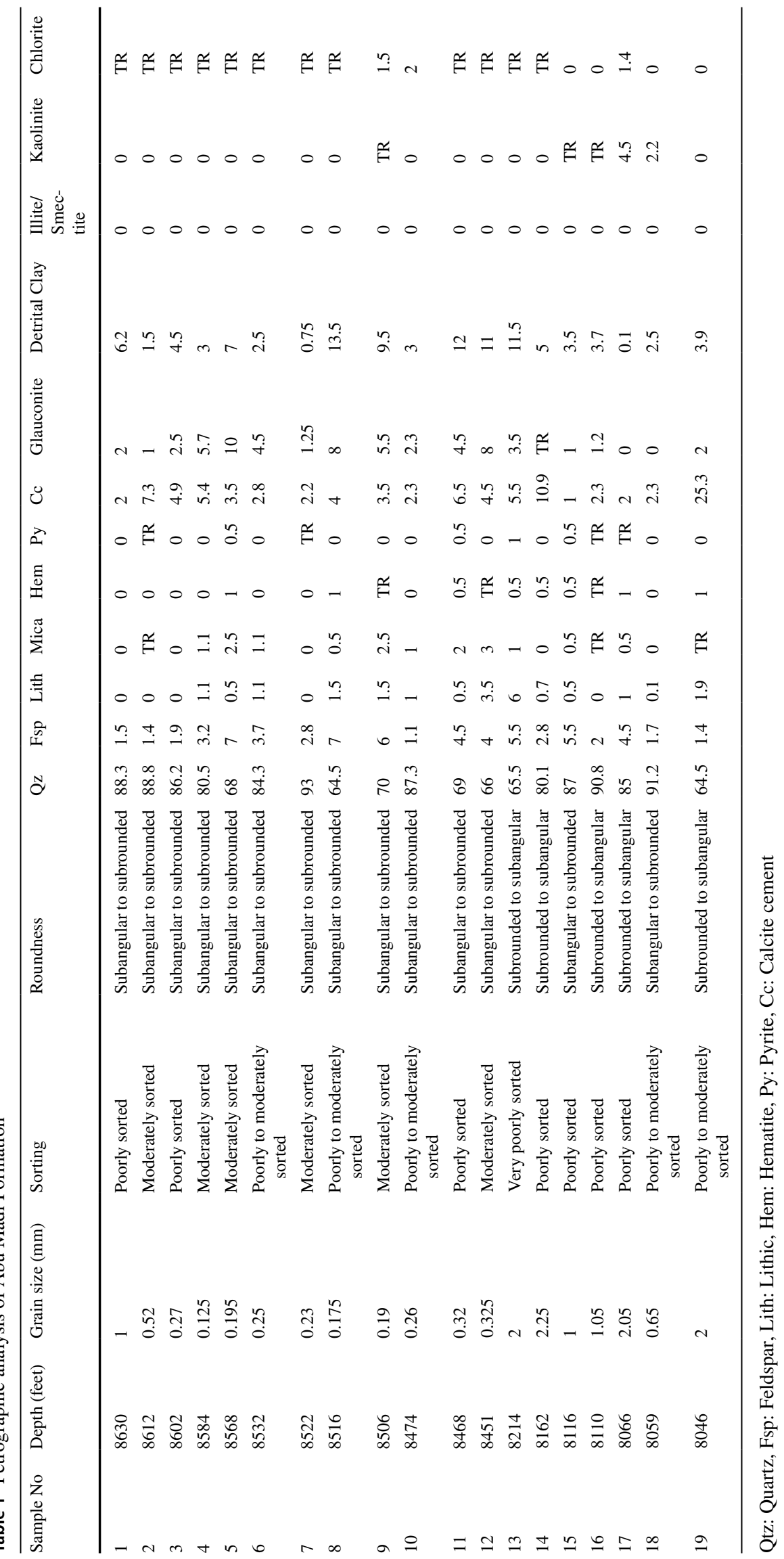




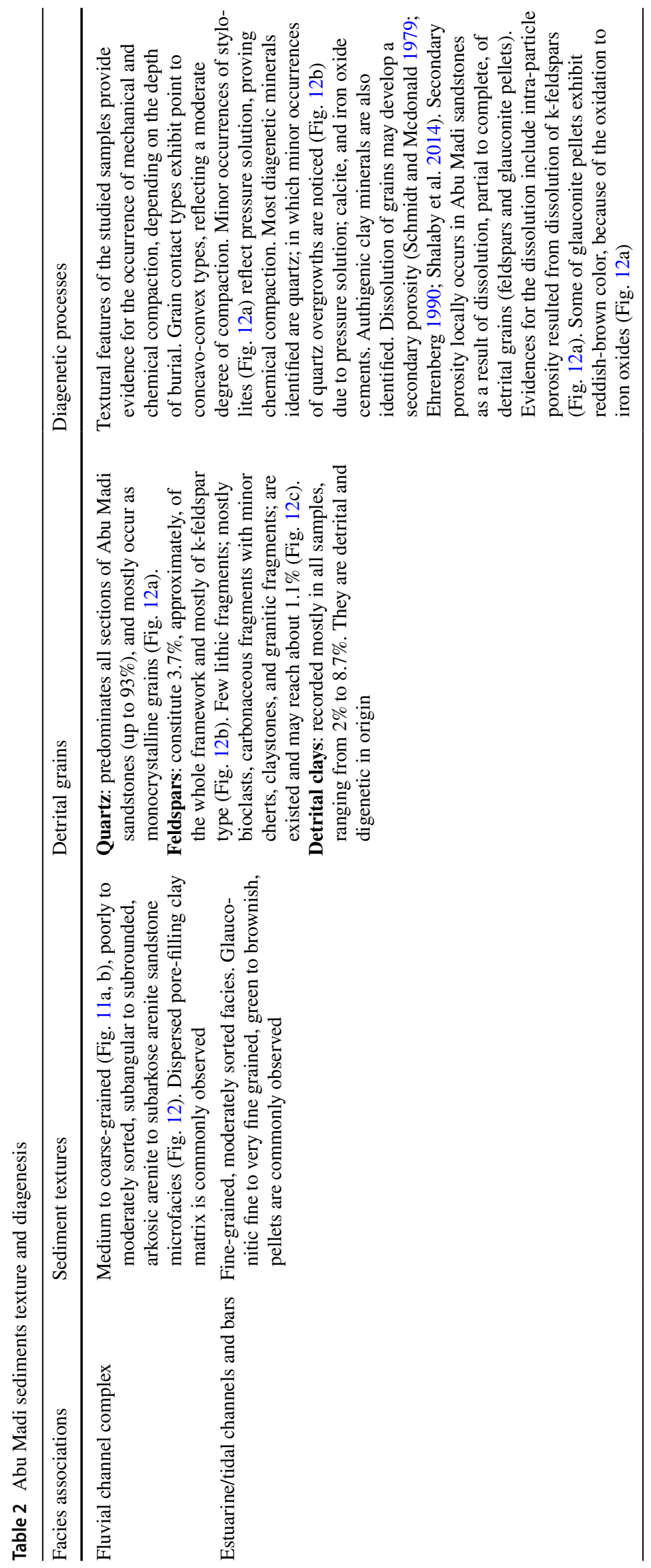



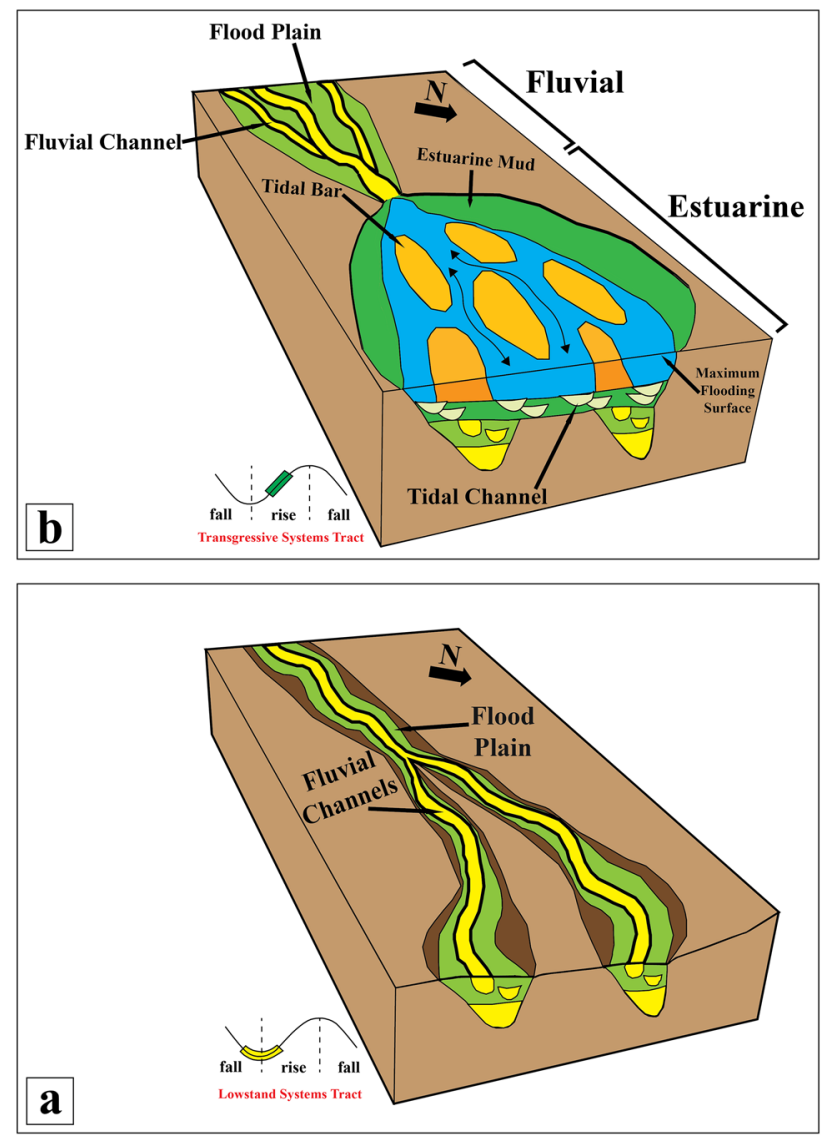

Fig. 13 Depositional model of MSC Abu Madi sequence, illustrating the evolution of depositional systems and facies associations, upon lowstand systems tract $\mathbf{a}$ and transgressive systems tract $\mathbf{b}$

\section{Conclusions}

(1) The RGB frequency fusion stratal slices depict the litho-morphological facies distribution of MSC Abu Madi incisions, showing a SW-NE trending reservoir fairway, with a Y-shape channel geometry.

(2) MSC Abu Madi Formation constitutes third-order sequence of fluvial to estuarine units infilling the Eonile-canyon, with five sedimentary facies associations (overbank muds, fluvial channel complex, tidal bars, tidal channels, and estuarine muds).

(3) The fluvial facies association is enriched with coarsegrained sandstones, deposited in subaerial setting, with considerably higher reservoir quality, in terms of porosity and permeability, acting as the best reservoir facies of the area.

(4) Depositional facies heterogeneity and diagenetic processes are the main factors controlling reservoir quality in the area. Although it is noticed that dissolution of feldspars has developed a secondary porosity of Abu Madi sediments, continental fluvial facies are the chief fluid flow conduits, where marine influence is limited.

(5) Consequently, adequately depicting the heterogeneity/ architecture, along with reservoir quality, of syn-MSC Abu Madi sediments, pointing to best sedimentary facies (fluvial channels), would give a robust insight into significant key parameters for future exploration and development strategies in the area.

(6) Furthermore, it is recommended to perform a further petroleum system-based approach, and sealing analysis, so as to define the entrapment and charge timing coincidence, along with identifying the migration pathways and best sites for hydrocarbon accumulation.

Acknowledgements The authors express their thanks to the Egyptian General Petroleum Corporation (EGPC), and Mansoura Petroleum Company, for providing the subsurface data needed for this work, and permitting publication. The authors are also grateful to geology departments of Menoufia and Al-Azhar universities for allowing access to laboratories equipped with needed facilities and software. Many thanks would go to journal's editor and reviewers for their help in refining the manuscript.

\section{Declarations}

Conflict of Interest There are no conflicts of interest.

Open Access This article is licensed under a Creative Commons Attribution 4.0 International License, which permits use, sharing, adaptation, distribution and reproduction in any medium or format, as long as you give appropriate credit to the original author(s) and the source, provide a link to the Creative Commons licence, and indicate if changes were made. The images or other third party material in this article are included in the article's Creative Commons licence, unless indicated otherwise in a credit line to the material. If material is not included in Madi sediments.

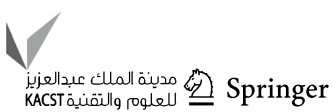


the article's Creative Commons licence and your intended use is not permitted by statutory regulation or exceeds the permitted use, you will need to obtain permission directly from the copyright holder. To view a copy of this licence, visit http://creativecommons.org/licenses/by/4.0/.

\section{References}

Abd El-Gawad EA, Abdelwahhab MA, Bekiet MH, Noah AZ, ElSayed NA, Fouda AEE (2019a) Reservoir quality determination through petrophysical analysis of El Wastani formation in Scarab field, offshore Nile Delta Egypt. Al-Azhar Bulletin of Science, 30(1-D), 1-12.

Abd El-Gawad EA, Abdelwahhab MA, Bekiet MH, Noah AZ, ElSayed NA, Fouda AEE (2019b) Static reservoir modeling of El Wastani formation, for justifying development plans, using 2D seismic and well log data in Scarab field, offshore Nile Delta Egypt. J Afr Earth Sci-Elsevier. https://doi.org/10.1016/j.jafrearsci.2019. 103546

Abd El-Wahed AG, Anan TI (2016) Detection of sedimentary structural elements using formation micro imager technique, a case study from South Mansoura-1 well, Nile Delta Egypt. NRIAG J Astron Geophys 5(2):413-434. https://doi.org/10.1016/j.nrjag. 2016.10.001

Abdel Aal A, Price RJ, Vaitl JD, \& Shrallow JA (1994) Tectonic evaluation of the Nile Delta, its impact on sedimentation and hydrocarbon potential. E.G.P.C. 12th Exploration and Production Conference 1:19-34

Abdel Aal A, El Barkooky A, Gerrits M, Meyer H, Schwander M, Zaki H (2000) Tectonic evolution of the Eastern Mediterranean Basin and its significance for hydrocarbon prospectivity in the ultradeepwater of the Nile Delta. Lead Edge 19(10):10861102. https://doi.org/10.1190/1.1438485

Abdel Aal A, El Barkooky A, Gerrits M, Meyer HJ, Schwander M, Zaki H (2001) Tectonic evolution of the Eastern Mediterranean Basin and its significance for the hydrocarbon prospectivity of the Nile delta deep-water area. GeoArabia 6:363-384

Abdel-Fattah MI (2014) Petrophysical characteristics of the Messinian Abu Madi Formation in the Baltim East and North fields, offshore Nile Delta Egypt. J Petrol Geol 37(2):183-195. https:// doi.org/10.1111/jpg.12577

Abdel-Fattah MI, Slatt RM (2013) Sequence Stratigraphic Controls on Reservoir Characterization and Architecture: Case study of the Messinian Abu Madi Incised-Valley Fill Egypt. Central Eur J Geosci 5(4):497-507. https://doi.org/10.2478/ s13533-012-0144-5

Abdel-Fattah MI, Tawfik AY (2015) 3D geometric modeling of the Abu Madi reservoirs and its implication on the gas development in Baltim Area (Offshore Nile Delta, Egypt). Int J Geophys 2015. https://doi.org/10.1155/2015/369143

Abdelwahhab MA, Raef A (2020) Integrated reservoir and basin modeling in understanding the petroleum system and evaluating prospects: The Cenomanian reservoir, Bahariya Formation, at Falak Field, Shushan Basin, Western Desert Egypt. J Pet Sci Eng-Elsevier. https://doi.org/10.1016/j.petrol.2020.107023

Abu El-Ata AS, El-Behiry MG, Hussein M (2019) Applications of the frequency analysis, using the spectral decomposition in the reservoir characterization. Geomech Geophys GeoEnergy Geo-Resour 5(4):457-478. https://doi.org/10.1007/ s40948-019-00118-z

Abu El-Ella R (1990) The Neogene-Quaternary section in the Nile Delta, Egypt: Geology and hydrocarbon potential. J Pet Geol
13(3):329-340. https://doi.org/10.1111/j.1747-5457.1990.tb008 $50 . \mathrm{x}$

Aigner T, Brandenburg A, van Vliet A, Doyle M, Lawrence D, Westrich J (1990) Stratigraphic modelling of epicontinental basins: two applications. Sed Geol 69(3-4):167-190. https:// doi.org/10.1016/0037-0738(90)90050-4

Allen P (2005) Striking a chord. Nature 434:961. https://doi.org/10. 1038/434961a

Allen PA (2008a) From landscapes into geological history. Nature, 451:274-276. https://doi.org/10.1038/nature06586

Allen PA (2008b) Time scales of tectonic landscapes and their sediment routing systems. In K. Gallagher, SJ Jones, \& J Wainwright (Eds.), Landscape Evolution: Denudation, Climate and Tectonics over Different Time and Space Scales (pp. 7-28). Geological Society, London, Special Publications, 296

Allen PA, Hovius N (1998) Sediment supply from landslide-dominated catchments: implications for basin-margin fans. Basin Res 10(1):19-35. https://doi.org/10.1046/j.1365-2117.1998.00060.x

Barber PM (1981) Messinian subaerial erosion of the proto-Nile Delta. Mar Geol 44(3-4):253-272. https://doi.org/10.1016/00253227(81)90053-0

Barsoum K, Della M, \& Kamal M (2002) Gas chimneys in the Nile Delta slope and gas field occurrence. MOC

Blatt H, \& Tracy RJ (1996) Petrology: Igneous, Sedimentary, and Metamorphic (2nd ed.). W H Freeman \& Co.

Bloch S (1991) Empirical prediction of porosity and permeability in sandstones. Am Asso Petrol Geol Bull 75(7):1145-1160

Braaksma H, Proust JN, Kenter JAM, Drijkoningen GG, Filippidou N (2006) Sedimentological, petrophysical, and seismic characterization of an upper jurassic shoreface-dominated shelf Margin (the Boulonnais, Northern France). J Sediment Res 76:175199. https://doi.org/10.2110/jsr.2006.11

Breda A, Mellere D, Massari F (2007) Facies and processes in a Gilbert-delta-filled incised valley (Pliocene of Ventimiglia, NW Italy). Sed Geol 200(1-2):31-55. https://doi.org/10.1016/j. sedgeo.2007.02.008

Bridge JS (2011) Fluvial Facies Models: Recent Developments. Facies Models Revisited. https://doi.org/10.2110/pec.06.84.0085

Cant D (1992) Subsurface facies analysis. In RG Walker \& JN (Eds.), Facies Models, Response to Sea Level Changes (pp. 27-45). Geol Assoc Canada

Catuneanu O, Khalifa MA, Wanas HA (2006) Sequence stratigraphy of the Lower Cenomanian Bahariya Formation, Bahariya Oasis, Western Desert Egypt. Sediment Geol 190:121-137. https://doi. org/10.1016/j.sedgeo.2006.05.010

Chopra S, Castagna JP (2014) AVO. Investigations in Geophysics Series No. 16, Society of Exploration Geophysicists. Tulsa, Oklahoma, U.S.A. https://doi.org/10.1190/1.9781560803201

Chopra S, \& Marfurt KJ (2007) Seismic attributes for prospect identification and reservoir characterization. In Seismic Attributes for Prospect Identification and Reservoir Characterization.

Chow JJ, Li MC, Fuh SC (2005) Geophysical well log study on the paleoenvironment of the hydrocarbon producing zones in the Erchungchi Formation, Hsinyin, SW Taiwan. Terr, Atmos Ocean Sci 16(3):531-545. https://doi.org/10.3319/TAO.2005.16.3. 531(T)

Cooke DA, Schneider WA (1983) Generalized linear inversion of reflection seismic data (USA). Geophysics 48(6):665-676. https://doi. org/10.1190/1.1441497

Corex (2007) Sedimentological and petrographic analyses on the cored Abu Madi Formation from West Al-Khilala Field wells, Nile Delta, Egypt

Dalla S, Harby H, Serazzi M (1997) Hydrocarbon exploration in a complex incised valley fill: An example from the late Messinian 
Abu Madi Formation (Nile Delta Basin, Egypt). Lead Edge 16(12):1819. https://doi.org/10.1190/1.1437590

Densmore AL, Allen PA, Simpson G (2007) Development and response of a coupled catchment fan system under changing tectonic and climatic forcing. J Geophys Res Earth Surf 112(1). https://doi. org/10.1029/2006JF000474

Dickinson W (1970) Interpreting detrital modes of greywacke and arkose. J Sediment Petrol 40:695-707. https://doi.org/10.1306/ 74D72018-2B21-11D7-8648000102C1865D

Dolson JC, Shann MV, Matbouly SI, Hammouda H, Rashed RM (2000) Egypt in the 21st century: petroleum potential in offshore trends. GeoArabia 6:211-230

Dolson JC, Shann MV, Matbouly S, Harwood C, Rashed R, \& Hammouda H (2001) The petroleum potential of Egypt. In: Downey MW, Threet JC, Morgan WA (Eds.), Petroleum Provinces of the 21st Century. AABG Memoir 74, pp. 453-482

Dumont T, Schwartz S, Guillot S, Simon-Labric T, Tricart P, Jourdan S (2012) Structural and sedimentary records of the Oligocene revolution in the Western Alpine arc. J Geodyn 56-57:18-38. https:// doi.org/10.1016/j.jog.2011.11.006

EGPC (1994) Nile Delta and North Sinai: Fields. The Egyptian General Petroleum Corporation, Discoveries and Hydrocarbon Potentials (A Comprehensive Overview)

Ehrenberg SN (1990) Relationship between diagenesis and reservoir quality in sandstones of the Garn Formation, Haltenbanken, mid-Norwegian Continental Shelf. Am Asso Petrol Geol Bull 74(10):1538-1558. https://doi.org/10.1306/0c9b2515-1710$11 \mathrm{~d} 7-8645000102 \mathrm{c} 1865 \mathrm{~d}$

El Nady MM (2007) Organic geochemistry of source rocks, condensates, and thermal geochemical modeling of miocene sequence of some wells, Onshore Nile Delta Egypt. Pet Sci Technol 25(6):791-818. https://doi.org/10.1080/10916460600803629

El Diasty WS, Moldowan JM (2013) The western desert versus Nile Delta: A comparative molecular biomarker study. Mar Pet Geol 46:319-334. https://doi.org/10.1016/j.marpetgeo.2013.07.003

El Khadragy AA, Eysa EA, Hashim A, Abd El Kader A (2017) Reservoir characteristics and 3D static modelling of the Late Miocene Abu Madi Formation, onshore Nile Delta Egypt. J Afr Earth Sci 132:99-108. https://doi.org/10.1016/j.jafrearsci.2017.04.032

El-Din ES, Mesbah MA, Kassab MA, Mohamed IF, Cheadle BA, Teama MA (2013) Assessment of petrophysical parameters of clastics using well logs: The upper miocene in ElWastani gas field, onshore Nile Delta, Egypt. Pet Explor Dev 40(4):488494. https://doi.org/10.1016/S1876-3804(13)60062-2

El-Mowafy HZ, Ibrahim M, Dunlap DB (2018) Unlocking gas reserves in bypassed stratigraphic traps in a deepwater brownfield using prestack seismic inversion: A case study from offshore Nile Delta Egypt. Lead Edge 37(7):502-509. https://doi.org/10.1190/tle37 070502.1

Emery D, Myers KJ (1996) Sequence stratigraphy. Blackwell Science Ltd. https://doi.org/10.1002/9781444313710

Esestime P, Hewitt A, Hodgson N (2016) Zohr-a newborn carbonate play in the Levantine Basin, East-Mediterranean. First Break 34:87-93. https://doi.org/10.3997/1365-2397.34.2.83912

Folk RL (1980) Petrology of sedimentary rock. Hemphill, Austin, Tex.

Garcia-Castellanos D, Estrada F, Jiménez-Munt I, Gorini C, Fernández M, Vergés J, De Vicente R (2009) Catastrophic flood of the Mediterranean after the Messinian salinity crisis. Nature 462(7274):778-781. https://doi.org/10.1038/nature08555

Gargani J, Rigollet C (2007) Mediterranean Sea level variations during the Messinian salinity crisis. Geophys Res Lett 34(10). https:// doi.org/10.1029/2007GL029885

Gargani J, Moretti I, Letouzey J (2008) Evaporite accumulation during the Messinian salinity crisis: The Suez rift case. Geophys Res Lett 35(2). https://doi.org/10.1029/2007GL032494
Gazzi P (1966) Le arenaire del fl ysch sopracretaceo dell'Appennino modenses: Correlazioni con il fl ysch di monghidoro. Mineral Petrogr Acta 12:69-97

Ghassal BI, El Atfy H, Sachse V, Littke R (2016) Source rock potential of the Middle Jurassic to Middle Pliocene, onshore Nile Delta Basin Egypt. Arab J Geosci 9:744. https://doi.org/10.1007/ s12517-016-2768-0

Griffin DL (1999) The late Miocene climate of northeastern Africa: Unravelling the signals in the sedimentary succession. J Geol Soc 156(4):817-826. https://doi.org/10.1144/gsjgs.156.4.0817

Griffin DL (2002) Aridity and humidity: Two aspects of the late Miocene climate of North Africa and the Mediterranean. Palaeogeogr Palaeoclimatol Palaeoecol 182(1-2):65-91. https://doi.org/10. 1016/S0031-0182(01)00453-9

Guiraud R, Bosworth W (1999) Phanerozoic geodynamic evolution of northeastern Africa and the northwestern Arabian platform. Tectonophysics 315(1-4):73-104. https://doi.org/10.1016/ S0040-1951(99)00293-0

Hanafy S, Nimmagadda SL, Mahmoud SE, Mabrouk WM, Farhood K (2016) Regional integrated interpretation of the hydrocarbon prospectivity of the Nile Delta Offshore Egypt. Arab J Geosci 9(5):376. https://doi.org/10.1007/s12517-016-2387-9

Hanafy S, Nimmagadda SL, Mahmoud SE, Mabrouk W (2017) New insights on structure and stratigraphic interpretation for assessing the hydrocarbon potentiality of the offshore Nile Delta basin Egypt. J Pet Explor Production Technol 7(2):317-339. https:// doi.org/10.1007/s13202-016-0264-4

Hanafy S, Farhood K, Mahmoud SE, Nimmagadda S, Mabrouk WM (2018) Geological and geophysical analyses of the different reasons for DHI failure case in the Nile Delta Pliocene section. J Pet Explor Prod Technol 8(4):969-981. https://doi.org/10.1007/ s13202-018-0445-4

Hardage BA., DeAngelo MV, Murray PE, Sava D (2011) Multicomponent seismic technology. Society of Exploration Geophysicists. P. 335. https://doi.org/10.1190/1.9781560802891

Harms JC, Wray JL (1990) Nile Delta. In Rushdi Said (Ed.) The geology of Egypt (pp. 329-343). AA.Balkema/Rotterdam/Brookfield.

Henry S (2000) Pitfalls in synthetics. Lead Edge 19(6):604. https://doi. org/10.1190/1.1438668

Hsü KJ, Ryan WBF, Cita MB (1973) Late miocene desiccation of the mediterranean. Nature 242(5395):240-244. https://doi.org/10. 1038/242240a0

Hussein M, El-Ata AA, El-Behiry M (2020) AVO analysis aids in differentiation between false and true amplitude responses: a case study of El Mansoura field, onshore Nile Delta Egypt. J Pet Explor Prod Technol 10(3):969-989. https://doi.org/10.1007/ s13202-019-00806-2

Kamel H, Eita T, Sarhan M (1998) Nile delta hydrocarbon potentiality. Egyptian General Petroleum Corporation (EGPC) 14th Exploration and Production Conference, pp. 485-503.

Kerdany MT, Cherif OH (1999) The mesozoic. In: Said R (ed) The geology of Egypt. Balkema, Rotterdam, pp 407-438

Keshta S, Metwalli FJ, Al Arabi HS (2012) Analysis of petroleum system for exploration and risk reduction in abu Madi/Elqar'a gas field, Nile Delta, Egypt. Int J Geophys 2012. https://doi.org/ $10.1155 / 2012 / 187938$

Kirschbaum MA, Schenk CJ, Charpentier RR, Klett TR, Brownfield ME, Pitman JK, Cook TA, Tennyson ME (2010) Assessment of undiscovered oil and gas resources of the Nile Delta Basin Province, Eastern Mediterranean. USGS Bulletin, Fact Sheet, 1-4. https://doi.org/10.3133/fs20103027

Krott D, Hilgers C, Bücker C (2015) Facies delineation by using a multivariate statistical model from onshore wells in the Nile Delta. Zeitschrift Der Deutschen Gesellschaft Fur Geowissenschaften 166(4):375-390. https://doi.org/10.1127/zdgg/2015/0040

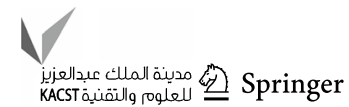


Lashin A, Mogren S (2012) Analysis of well log and pressure data of the gas-bearing sand reservoirs of Kafr El-Sheikh formation: case study from the off-shore Nile Delta- Egypt. Int J Geophys 7(35):5353-5366. https://doi.org/10.5897/ijps12.475

Latimer RB, Davidson R, Van Riel P (2000) An interpreter's guide to understanding and working with seismic-derived acoustic impedance data. Lead Edge 19(3):242-256. https://doi.org/10. $1190 / 1.1438580$

Legarreta L, \& Uliana MA (1998) Anatomy of hinterland depositional sequences: upper cretaceous fluvial strata, Neuquen Basin, westcentral Argentina. In Relative role of eustasy, climate, and tectonism in continental rocks.

Leila M (2019) Clay minerals distribution in the pre-, syn-Messinian salinity crisis sediments of the onshore Nile Delta, Egypt: Mineral origin and implications on the reservoir quality. J Afr Earth Sc 154:35-48. https://doi.org/10.1016/j.jafrearsci.2019.03.016

Leila M, Mohamed A (2020) Diagenesis and petrophysical characteristics of the shallow Pliocene sandstone reservoirs in the Shinfas Gas Field, onshore Nile Delta Egypt. J Pet Explor Prod Technol 10(5):1743-1761. https://doi.org/10.1007/s13202-020-00873-w

Leila M, Moscariello A (2017) Organic geochemistry of oil and natural gas in the West Dikirnis and El-Tamad fields, onshore Nile Delta, Egypt: Interpretation of potential source rocks. J Pet Geol 40(1):37-58. https://doi.org/10.1111/jpg.12663

Leila M, Moscariello A (2019) Seismic stratigraphy and sedimentary facies analysis of the pre- and syn- Messinain salinity crisis sequences, onshore Nile Delta, Egypt: Implications for reservoir quality prediction. Mar Pet Geol 101:303-321. https://doi.org/10. 1016/j.marpetgeo.2018.12.003

Leila M, Kora MA, Ahmed MA, Ghanem A (2016) Sedimentology and reservoir characterization of the Upper Miocene Qawasim Formation, El-Tamad Oil Field onshore Nile Delta Egypt. Arab J Geosci 9(1):1-13. https://doi.org/10.1007/s12517-015-2088-9

Leila M, Moscariello A, Šegvić B (2018) Geochemical constraints on the provenance and depositional environment of the Messinian sediments, onshore Nile Delta, Egypt: Implications for the late Miocene paleogeography of the Mediterranean. J Afr Earth Sc 143:215-241. https://doi.org/10.1016/j.jafrearsci.2018.03.024

Leila M, Moscariello A, Šegvić B (2019) Depositional facies controls on the diagenesis and reservoir quality of the Messinian Qawasim and Abu Madi formations, onshore Nile Delta Egypt. Geol J 54(3):1797-1813. https://doi.org/10.1002/gj.3269

Leila M, Moscariello A, Kora M, Mohamed A, Samankassou E (2020) Sedimentology and reservoir quality of a Messinian mixed siliciclastic- carbonate succession, onshore Nile Delta Egypt. Marine Pet Geol 112:104076. https://doi.org/10.1016/j.marpetgeo.2019. 104076

Liu Q, Zhu X, Yang Y, Geng M, Tan M, Jiang L, Chen L (2016) Sequence stratigraphy and seismic geomorphology application of facies architecture and sediment-dispersal patterns analysis in the third member of Eocene Shahejie Formation, slope system of Zhanhua Sag, Bohai Bay Basin, China. Mar Pet Geol 78:766-784. https://doi.org/10.1016/j.marpetgeo.2015.11.015

Loncke L, Gaullier G, Bellaiche G, Mascle J (2002) Recent depositional patterns of the Nile deep-sea fan from echo- character mapping. AAPG Bull 86:1165-1186. https://doi.org/10.1306/ 61eedc42-173e-11d7-8645000102c1865d

Makled WA, Mandur MMM, Langer MR (2017) Neogene sequence stratigraphic architecture of the Nile Delta, Egypt: A micropaleontological perspective. Mar Pet Geol 85:117-135. https://doi. org/10.1016/j.marpetgeo.2017.04.017

Martin R (1966) Paleogeomorphology and its application to exploration for oil and gas (with examples from Western Canada). Aapg Bulletin. https://doi.org/10.1306/5d25c285-16c1-11d7-86450 $00102 \mathrm{c} 1865$
Masini E, Manatschal G, Mohn G, Ghienne JF, Lafont F (2011) The tectono-sedimentary evolution of a supra-detachment rift basin at a deep-water magma-poor rifted margin: The example of the Samedan Basin preserved in the Err nappe in SE Switzerland. Basin Res 23(6):652-677. https://doi.org/10.1111/j.1365-2117. 2011.00509.x

Masrouhi A, Ghanmi M, Slama MM, Ben Y, Ben M, Vila JM, Zargouni F (2008) New tectono-sedimentary evidence constraining the timing of the positive tectonic inversion and the Eocene Atlasic phase in northern Tunisia: Implication for the North African paleo-margin evolution. Comptes Rendus-Geosci 340(11):771778. https://doi.org/10.1016/j.crte.2008.07.007

Miall AD (1977) A review of the braided-river depositional environment. Earth-Sci Rev 13(1):1-62. https://doi.org/10.1016/00128252(77)90055-1

Miall AD (1996) The geology of fluvial deposits: sedimentary facies, basin analysis, and petroleum geology. In The geology of fluvial deposits: sedimentary facies, basin analysis, and petroleum geology.

Miall, A. D. (2010). The geology of stratigraphic sequences: Second edition. In The geology of stratigraphic sequences: Second edition.

Mitchum RM, Vail PR, \& Thompson S (1977). Seismic stratigraphy and global changes of sea level, Part 2: The depositional sequence as a basic unit for stratigraphic analysis. In CE Payton (Ed.), Seismic stratigraphy - applications to hydrocarbon exploration. American Association of Petroleum Geologists, Memoir 26, pp. 53-62

Mohamed A, Ibrahim E, Sabry A (2013) Petrophysical characteristics of Wakar Formation, Port Fouad marine field, north Nile Delta Egypt. Arab J Geoscis 6(5):1485-1497. https://doi.org/10.1007/ s12517-011-0446-9

Nabawy BS, Shehata AM (2015) Integrated petrophysical and geological characterization for the Sidi Salem-Wakar sandstones, off-shore Nile Delta Egypt. J Afr Earth Sci 110:160-175. https:// doi.org/10.1016/j.jafrearsci.2015.06.017

Nashaat M (1998) Abnormally high formation pressure and seal impacts on hydrocarbon accumulations in the Nile Delta and North Sinai basins, Egypt. AAPG Memoir 70: Abnormal Pressures in Hydrocarbon Environments 70:161-180. https://doi.org/ 10.1306/M70615C10

Nazeer A, Abbasi SA, Solangi SH (2016) Sedimentary facies interpretation of Gamma Ray (GR) log as basic well logs in Central and Lower Indus Basin of Pakistan. Geodesy Geodyn 7(6):432443. https://doi.org/10.1016/j.geog.2016.06.006

Niazi M, \& Dahi M (2004). Un-Explored Giant Sandstone Features In Ultra-deep water, West Mediterranean, Egypt. AAPG International Conference: pp. 24-27.

Partyka G, Gridley J, Lopez J (1999) Interpretational applications of spectral decomposition in reservoir characterization. Lead Edge 18(3):353-360. https://doi.org/10.1190/1.1438295

Pettijohn FJ, Potter PE, Siever R (1972) Sand and Sandstone. SpringerVerlag, Berlin

Pigott J, Abdel-Fattah M (2014) Seismic stratigraphy of the Messinian Nile Delta coastal plain: recognition of the fluvial regressive systems tract and its potential for hydrocarbon exploration. J Afr Earth Sci 95:9-21. https://doi.org/10.1016/j.jafrearsci.2014.02. 003

Posamentier HW (2004). Seismic Geomorphology: Imaging Elements of Depositional Systems from Shelf to Deep Basin Using 3D Seismic Data: Implications for Exploration and Development. In RJ Davies, JA Cartwright, SA Stewart, M Lappin, \& JR Underhill (Eds.), 3D Seismic Technology: Applications to the Exploration of Sedimentary Basins. Memoirs 29 Geological Society, London pp. 11-24. 
Posamentier HW, \& Vail PR (1988) Eustatic controls on clastic deposition II: Sequence and systems tract models. In CK Wilgus, BS Hastings, CGS C Kendall, HW Posamentier, CA Ross, \& JC Van Wagoner (Eds.), Sea-level changes: an integrated approach. SEPM, Special Publication 42, pp. 125-154

Posamentier HW, Davies RJ, Cartwright JA, Wood LJ (2007) Seismic geomorphology-An overview. Geol Soc, London, Spec Publ 277(1):1. https://doi.org/10.1144/GSL.SP.2007.277.01.01

Prizomwala SP, Bhatt N, Basavaiah N (2014) Provenance discrimination and Source-to-Sink studies from a dryland fluvial regime: An example from Kachchh, western India. Int J Sedim Res 29(1):99-109. https://doi.org/10.1016/S1001-6279(14)60025-1

Reineck HE, Singh IB (1980) Depositional sedimentary environments, with reference to terrigenous clastics. Springer-Verlag Berlin Heidelberg. https://doi.org/10.1007/978-3-642-81498-3

Richards M, Bowman M, Reading H (1998) Submarine-fan systems I: characterization and stratigraphic prediction. Mar Pet Geol 15(7):689-717. https://doi.org/10.1016/S0264-8172(98)00036-1

Rizzini A, Vezzani F, Cococcetta V, Milad G (1978) Stratigraphy and sedimentation of a Neogene-Quaternary section in the Nile Delta area (A.R.E.). Mar Geol 27(3-4):327-348. https://doi.org/10. 1016/0025-3227(78)90038-5

Ross D, Uchupi E (1977) Structure and sedimentary history of Southeastern Mediterranean Sea-Nile cone area. AAPG Bull 61:872902. https://doi.org/10.1306/C1EA4397-16C9-11D7-86450 00102C1865D

Russell B, Hampson D (1991) Comparison of poststack seismic inversion methods. SEG Annual Meet 1991:876-878. https://doi.org/ $10.1190 / 1.1888870$

Ryan WBF, Hsu KJ, Chumakov IS (1973) Geological history of the Mediterranean at the end of the miocene-the beginning of the pliocene according to new data. In Initial Reports of the Deep Sea Drilling Project, 13.

Said R (1962) The geology of Egypt. Elsevier Publishing company, Amsterdam

Said R (1981) The geological evolution of the river nile: Vol. viii (2009/05/01). Springer Verlag.

Said R (1990) The geology of Egypt. A.A.Balkema, Rotterdam

Saleh S (2012) 3D crustal structure and its tectonic implication for Nile Delta and Greater Cairo regions, Egypt, from geophysical data. Acta Geodaetica et Geophysica Hungarica 47(4):402429. https://doi.org/10.1556/AGeod.47.2012.4.3

Saleh S (2013) The role of geophysical and seismological data in evaluating the subsurface structures and tectonic trends of Nile Delta Egypt. Arab J Geosci 6(9):3201-3216. https://doi.org/10.1007/ s12517-012-0603-9

Salem AM, Ketzer JM, Morad S, Rizk RR, Al-Aasm IS (2005) Diagenesis and reservoir-quality evolution of incised-valley sandstones: Evidence from the Abu Madi gas reservoirs (Upper Miocene), the Nile Delta Basin Egypt. J Sediment Res 75(4):572-584. https:// doi.org/10.2110/jsr.2005.047

Samuel A, Kneller B, Raslan S, Sharp A, Parsons C (2003) Prolific deep marine slope channels of the Nile Delta Egypt. AAPG Bullet 87(4):541-560. https://doi.org/10.1306/1105021094

Sarhan M, Hemdan K (1994) North Nile Delta structural setting trapping and mechanism. EGPC 12th Expl Prod Conf 1:1-18

Schlumberger (1984). Well Evaluation Conference. Egypt: chapter 1 Geology of Egypt. Schlumberger Limited: Texas

Schmidt V, Mcdonald DA (1979) Texture and recognition of secondary porosity in sandstones. SEPM (Society for Sedimentary Geology), 209-225. https://doi.org/10.2110/pec.79.26.0209

Seidel M, Seidel E, Stöckhert B (2007) Tectono-sedimentary evolution of lower to middle Miocene half-graben basins related to an extensional detachment fault (western Crete, Greece). Terra Nova 19(1):39-47. https://doi.org/10.1111/j.1365-3121.2006.00707.x
Selim SS (2016) Sedimentological architecture, shelf-edge trajectories and evolution of an Oligocene reservoir East Nile Delta. Geol Mag 155(3):747-771. https://doi.org/10.1017/S00167568160005 22

Selley RC (1978) Concepts and methods of subsurface facies analysis (pp. 9-82). American Association of Petroleum Geologists Contin Educ Course Notes Ser. https://doi.org/10.1306/ce9397

Sestini G (1989) Nile delta: a review of depositional environments and geological history. In: Whateley, M.K.G., Picker- ing, K.T. (Eds.), Deltas: Sites and traps for fossil fuels, Geological Society Special Publication, 41, 99-127.

Sestini G (1995) Egypt. In H. Kulke (Ed.), Regional petroleum geology of the world, Part II: Africa, America, Australia and Antarctica (vol. 22, pp. 66-87). Beiträge zur regionalen Geologie der Erde.

Shaaban F, Lutz R, Littke R, Bueker C, Odisho K (2006) Source-rock evaluation and basin modelling in NE Egypt (NE Nile Delta and northern Sinai). J Pet Geol 29(2):103-124. https://doi.org/10. 1111/j.1747-5457.2006.00103.x

Shalaby MR, Hakimi MH, Abdullah WH (2014) Diagenesis in the Middle Jurassic Khatatba Formation sandstones in the Shoushan Basin, northern Western Desert Egypt. Geol J 49(3):239255. https://doi.org/10.1002/gj.2512

Shanley KW, McCabe PJ (1994) Perspectives on the sequence stratigraphy of continental strata. Am Asso Petrol Geol Bull 78(4):544568. https://doi.org/10.1306/bdff9258-1718-11d7-8645000102 c1865d

Sharaf L, Awad S, Khaled K, \& Rashed A (2004) Sedimentology and reservoir characterization of the Abu Madi level III sandstones, Abu Madi gas field, Nile delta, Egypt. 7th Inter Conf Geol Arab Wor 457-481.

Slatt R (2006) Stratigraphic reservoir characterization for petroleum geologists, geophysicists, and engineers. Elsevier Science Limited, Amsterdam

Slatt RM (2013) Stratigraphic Reservoir Characterization for Petroleum Geologists, Geophysicists, and Engineers. Elsevier B.V.

Sømme TO, Jackson CAL (2013) Source-to-sink analysis of ancient sedimentary systems using a subsurface case study from the Møre-Trøndelag area of southern Norway: Part 2 - sediment dispersal and forcing mechanisms. Basin Res 25(5):512531. https://doi.org/10.1111/bre.12014

Sømme TO, Helland-hansen W, Martinsen OJ, Thurmond JB (2009) Relationships between morphological and sedimentological parameters in source-to-sink systems: A basis for predicting semi-quantitative characteristics in subsurface systems. Basin Res 21(4):361-387. https://doi.org/10.1111/j.1365-2117.2009. 00397.x

Sømme TO, Jackson CAL, Vaksdal M (2013) Source-to-sink analysis of ancient sedimentary systems using a subsurface case study from the Møre-Trøndelag area of southern Norway: Part 1 - depositional setting and fan evolution. Basin Res 25(5):489511. https://doi.org/10.1111/bre.12013

Subrahmanyam D, \& Rao PH (2008) Seismic Attributes-A Review. 7th International Conference and Exposition on Petroleum Geophysics.

Teama MA, Kassab MA, Cheadle BA, Mesbah MA, Mohamed IF, ElDin ES (2018) 3D seismic and formation micro-imager (FMI) integrated study to delineate depositional pattern of Abu Madi (Upper Miocene) clastic reservoir rocks in El-Wastani gas field, onshore Nile Delta, Egypt. Egypt J Pet 27(4):747-758. https:// doi.org/10.1016/j.ejpe.2017.11.003

Tucker ME (2001) Sedimentary petrology. An introduction to the orgin of sedimentary rocks. In Geoscience Texts. Wiley, New Jersy

Vandré C, Cramer B, Gerling P, Winsemann J (2007) Natural gas formation in the western Nile delta (Eastern Mediterranean): Thermogenic versus microbial. Org Geochem 38(4):523-539. https:// doi.org/10.1016/j.orggeochem.2006.12.006

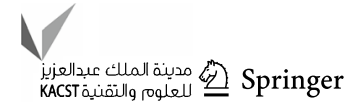


White R, Simm R (2003) Tutorial: Good practice in well ties. First Break 21(10):75-83. https://doi.org/10.3997/1365-2397.21.10. 25640

Wright VP, Marriott SB (1993) The sequence stratigraphy of fluvial depositional systems: the role of floodplain sediment storage. Sediment Geol 86(3-4):203-210. https://doi.org/10.1016/00370738(93)90022-W

Yassin MA, Hariri MM, Abdullatif OM, Makkawi M, Bertotti G, Kaminski MA (2018) Sedimentologic and reservoir characteristics under a tectono- sequence stratigraphic framework: A case study from the Early Cretaceous, upper Abu Gabra sandstones, Sufyan Sub-basin, Muglad Basin, Sudan. J Afr Earth Sc 142:2243. https://doi.org/10.1016/j.jafrearsci.2018.02.015

Younis A, El-Qady G, Abd Alla M, Abdel Zaher M, Khalil A, Al Ibiary M, Saraev A (2015) AMT and CSAMT methods for hydrocarbon exploration at Nile Delta Egypt. Arab J Geosci 8(4):19651975. https://doi.org/10.1007/s12517-014-1354-6

Zaghloul, Z. M. (1976). Stratigraphy of the Nile Delta. Seminar Nile Delta Sediment, UNESCO, 40-49.

Zaitlin B, Dalrymple R, \& Boyd R (1994). The stratigraphic organization of incised-valley systems associated with relative sea-level changes. In R. Dalrymple, R. Boyd, \& B. Zaitlin (Eds.), Incisedvalley Systems: Origin and Sedimentary Sequences. SEPM Spec Publ 51, pp. 45-60

Zeng H (2017) Thickness imaging for high-resolution stratigraphic interpretation by linear combination and color blending of multiple-frequency panels. Interpretation 5(3):T411-T422. https:// doi.org/10.1190/INT-2017-0034.1

Zeng H, Hentz TF (2004) High-frequency sequence stratigraphy from seismic sedimentology: Applied to Miocene, Vermilion Block
50, Tiger Shoal area, offshore Louisiana. Am Asso Petrol Geol Bull 88(2):153-174. https://doi.org/10.1306/10060303018

Zeng H, Henry SC, Riola JP (1998b) Stratal slicing, Part II: Real 3-D seismic data. Geophysics 63(2):514-522. https://doi.org/10. $1190 / 1.1444352$

Zeng H, Backus MM, Barrow KT, Tyler N (1998a) Stratal slicing, Part I: Realistic 3-D seismic model. Geophysics 63(2):502513. https://doi.org/10.1190/1.1444351

Zeng H, Zhu X, Liu Q, Zhu H, Xu C (2020) An alternative, seismicassisted method of fluvial architectural-element analysis in the subsurface: Neogene, Shaleitian area, Bohai Bay Basin. China Marine Pet Geol 118:104435. https://doi.org/10.1016/j.marpe tgeo.2020.104435

Zhu H, Yang X, Zhou X, Liu K (2014) Three-dimensional facies architecture analysis using sequence stratigraphy and seismic sedimentology: Example from the Paleogene Dongying formation in the BZ3-1 block of the Bozhong Sag, Bohai Bay Basin, China. Mar Pet Geol 51:20-33. https://doi.org/10.1016/j.marpe tgeo.2013.11.014

Ziolkowski A, Underhill JR, Johnston RGK (1998) Wavelets, well ties, and the search for subtle stratigraphic traps. Geophysics 63(1):297-313. https://doi.org/10.1190/1.1444324

Publisher's Note Springer Nature remains neutral with regard to jurisdictional claims in published maps and institutional affiliations. 